\title{
Megafauna of vulnerable marine ecosystems in French mediterranean submarine canyons: Spatial distribution and anthropogenic impacts
}

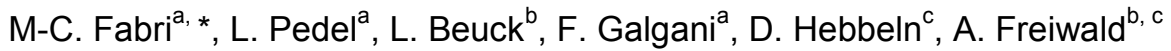

\author{
a Ifremer, Département Océanographie et Dynamique des Ecosystèmes, 83500 La Seyne sur Mer, France \\ ${ }^{b}$ Senckenberg am Meer, Marine Research Department, Südstrand 40, 26382 Wilhelmshaven, Germany \\ ${ }^{\mathrm{c}}$ MARUM - Center for Marine Environmental Sciences, Leobener Strasse, 28359 Bremen, Germany \\ *: Corresponding author : Marie-Claire Fabri, tel.: +33 4943048 05; fax: +334943044 17 ; \\ email address : Marie.Claire.Fabri@ifremer.fr
}

\begin{abstract}
:
Vulnerable Marine Ecosystems (VME) in the deep Mediterranean Sea have been identified by the General Fisheries Commission for the Mediterranean as consisting of communities of Scleractinia (Lophelia pertusa and Madrepora oculata), Pennatulacea (Funiculina quadrangularis) and Alcyonacea (Isidella elongata). This paper deals with video data recorded in the heads of French Mediterranean canyons. Quantitative observations were extracted from 101 video films recorded during the MEDSEACAN cruise in 2009 (Aamp/Comex). Qualitative information was extracted from four other cruises (two Marum/Comex cruises in 2009 and 2011 and two Ifremer cruises in 1995 and 2010) to support the previous observations in the Cassidaigne and Lacaze-Duthiers canyons. All the species, fishing impacts and litter recognized in the video films recorded from 180 to $700 \mathrm{~m}$ depth were mapped using GIS. The abundances and distributions of benthic fishing resources (marketable fishes, Aristeidae, Octopodidae), Vulnerable Marine Species, trawling scars and litter of 17 canyons were calculated and compared, as was the open slope between the Stoechades and Toulon canyons. Funiculina quadrangularis was rarely observed, being confined for the most part to the Marti canyon and, I. elongata was abundant in three canyons (Bourcart, Marti, Petit-Rhône). These two cnidarians were encountered in relatively low abundances, and it may be that they have been swept away by repeated trawling. The Lacaze-Duthiers and Cassidaigne canyons comprised the highest densities and largest colony sizes of scleractinian cold-water corals, whose distribution was mapped in detail. These colonies were often seen to be entangled in fishing lines. The alcyonacean Callogorgia verticillata was observed to be highly abundant in the Bourcart canyon and less abundant in several other canyons. This alcyonacean was also severely affected by bottom fishing gears and is proposed as a Vulnerable Marine Species. Our studies on anthropogenic impacts show that seafloor disturbance by benthic fishing is mainly attributable to trawling in the Gulf of Lion and to long lines where rocky substrates are present. The bauxite residue (red mud) expelled in the Cassidaigne canyon was seen to prevent fauna from settling at the bottom of the canyon and it covered much of the flanks. Litter was present in all of the canyons and especially in considerable quantities in the Ligurian Sea, where the heads of the canyons are closer to the coast. Three Marine Protected Areas and one fishing area with restricted access have recently been established and should permit the preservation of these deep ecosystems.
\end{abstract}

Keywords : Seafloor mapping ; Biodiversity ; Bathyal-benthic zone ; Cold-water coral ; Litter ; Fishing impact ; Bauxite red mud waste ; Mediterranean Sea ; French submarine canyons $\left(43^{\circ} \mathrm{N}, 5^{\circ} \mathrm{E}\right)$ 


\section{Introduction}

There has been increasing societal demand for the conservation of biodiversity since the Convention on Biological Diversity recognised the intrinsic value of biological diversity and its ecological, genetic, social, economic, scientific, educational, cultural and recreational benefits at the 1992 Earth Summit in Rio de Janeiro (http://www.cbd.int/). Considerable efforts have been made in recent years through the ten-year Census of Marine Life Project to estimate biodiversity in the oceans (Costello et al., 2010). Nevertheless the total number of marine species is still unknown because many species remain to be sampled, distinguished and described (Bouchet, 2006). Less is known about deep-sea areas compared to coastal environments due to the practical difficulties of sampling deeper waters. However, there is a pronounced shift of fisheries from shallow to much deeper regions, motivated by the declining fish stocks on the continental shelves (Cartes et al., 2004) and by the advanced fishing gear technology now available for the efficient exploitation of the bathyal zone. Despite this, deep-water ecosystems are characterized by low productivity, low fecundity, older age at first maturity and high longevity of the species adapted to these environments; thus they are highly sensitive to commercial exploitation.

Adverse impacts to Vulnerable Marine Ecosystems (VME) in the deep sea have now become an international concern since the United Nations called on governments and Regional Fishery Management Organisations to prevent them (United Nation, 2007). The Food and Agriculture Organisation (FAO) has formulated management guidelines, by setting up an international consultative process and determining criteria for defining VMEs (FAO, 2009). The latter include uniqueness or rarity of species or habitat, their functional significance, fragility and structural complexity, and life histories that limit the probability of recovery. Examples of taxa indicative of a VME are given associated with specific undersea landscape types, but no explicit metrics, threshold values, or analytical approaches are given for identifying whether one area contains a VME and another does not (Auster et al., 2011). The biggest constraints in protecting VMEs are the uncertainties in the distribution and abundance of VME indicator species, and similar uncertainties in the link between fishing intensity and significant adverse impacts. The Convention for the Protection of the Marine Environment of the North-East Atlantic (OSPAR for Oslo-Paris) has worked to identify the threats to the marine environment and has pioneered the development of methods for monitoring and assessing the quality status of seas. The OSPAR Commission has established a list of threatened and/or declining species and habitats in the OSPAR maritime area that require protection. The deepsea habitats mentioned in the OSPAR list are coral gardens, Lophelia pertusa reefs, deep-sea sponge aggregation and sea-pen and burrowing megafauna communities (http://www.ospar.org).

Compared to the adjacent deep Atlantic basins the Mediterranean Sea is a warm, deep, oligotrophic basin where temperatures remain largely uniform but at much higher levels, i.e. around $12.5-14.5^{\circ} \mathrm{C}$ below $150 \mathrm{~m}$, with high salinity (38.4-39.0) and high oxygen levels (4.5-5.0 $\mathrm{ml} \mathrm{l}^{-1}$ ) (Cartes et al., 2004). The western Mediterranean basin is connected to the Atlantic by the narrow Strait of Gibraltar, with a sill depth of about $300 \mathrm{~m}$, and to the eastern Mediterranean basin by the Sicily Channel $(400 \mathrm{~m})$. These gateways funnel the entire exchange of water mass between the eastern and western basin (Sicily Channel) and with the Atlantic Ocean (Strait of Gibraltar), thereby following the pattern of anti-estuarine circulation (Astraldi et al., 1999). These features distinguish Mediterranean deep-sea communities as being potentially unique and particularly sensitive to human activities. The continental shelves are narrow, except close to the outlets of major rivers (the Rhône in the western basin) (Cartes et al., 2004) and are incised by numerous submarine canyons. Much of the Mediterranean coast has deep-water bottoms near the shore, typically reached within a few hours by commercial vessels. The Mediterranean stands out as a globally different region because its canyons are more closely spaced $(14.9 \mathrm{~km})$, more dendritic $\left(12.9\right.$ limbs per $\left.100,000 \mathrm{~km}^{2}\right)$, shorter (mean length of $26.5 \mathrm{~km}$ ) and steeper (mean slope of $6.5^{\circ}$ ) than canyons found in other regions of the world (Harris and Whiteway, 2011).

The General Fisheries Commission for the Mediterranean (GFCM) has issued a list of criteria for the identification of sensitive habitats of relevance for the management of priority species in the Mediterranean Sea (GFCM, 2009a). The GFCM has also issued a list of identified sensitive habitats including: (1) cold-water corals (Lophelia pertusa and Madrepora oculata communities) which form 
colonies supported by a common skeleton, providing a structural habitat for other species (Peres and Picard, 1964; Zibrowius, 1980); (2) soft mud facies with Funiculina quadrangularis (Bellan-Santini et al., 2002; Peres and Picard, 1964), which is an essential habitat for certain crustacean species (Parapenaeus longirostris and Nephrops norvegicus); and (3) compact mud facies with Isidella elongata (Bellan-Santini et al., 2002; Maurin, 1962; Peres and Picard, 1964), which is a relevant habitat for red shrimps (Aristeus antennatus and Aristaeomorpha foliacea). These habitats are potentially vulnerable as they are targeted by fisheries. Another anthropogenic pressure affecting seafloor integrity includes silting which can change the environmental conditions of the habitats. For instance the Cassidaigne canyon, near Marseille, France, has received red mud discharged by the Gardanne Aluminium factory since 1967. Red mud extends into the abyssal plain more than $50 \mathrm{~km}$ away from the pipe (Dauvin, 2010; Fontanier et al., 2012).

All the pressures on natural marine resources and the demand for marine ecological services are considered excessive and have led to the establishment of the European Marine Strategy Framework Directive (MSFD). This marine environmental policy established in 2008 aims at reducing impacts on marine waters, by considering that the marine environment is a precious heritage that must be protected, preserved and, where practicable, restored, with the ultimate aim of maintaining biodiversity and providing diverse and dynamic oceans and seas which are clean, healthy and productive. The final objective of the MSFD is to achieve or maintain good environmental status in the marine environment by 2020 at the latest. The work described in this paper was performed in the framework of the initial assessment of the bathyal benthic ecosystems in the French submarine canyons of the Mediterranean Sea.

We used a Geographic Information System (GIS) to map all the species and ecosystems recognized on video films recorded during the MEDSEACAN cruise in 2009 (Watremez, 2012), the MARUM cruise in 2009, the MARUM-Senckenberg cruise in 2011, the Ifremer ESSROV cruise in 2010 and the CYATOX cruise in 1995. We assessed their spatial distribution from $180 \mathrm{~m}$ to $700 \mathrm{~m}$ depth in the heads of French canyons. Three objectives were pursued: (1) mapping benthic fishing resources; (2) mapping Vulnerable Marine Ecosystems recognised by the General Fisheries Commission for the Mediterranean (GFCM, 2009a); and (3) assessing the distribution and threat of anthropogenic impacts on benthic ecosystems including fishing activities and waste disposal.

\section{Materials and methods}

\subsection{Study area}

The study area covers the shelf break and the bathyal zone of the French continental margin of the northwest Mediterranean Sea, stretching from $42^{\circ} 30^{\prime} \mathrm{N}$ to $43^{\circ} 30^{\prime} \mathrm{N}$ and from 3 to $7^{\circ} \mathrm{E}$. This continental slope is divided into two regions, namely the Gulf of Lion and the French Riviera (Ligurian Sea). The Gulf of Lion has a broad shelf (wider than $100 \mathrm{~km}$ ) with a gentle slope, stretching from the coast to the shelf break. The continental shelf off the French Riviera is narrow $(2-20 \mathrm{~km}$ wide) with a steep slope. The French continental slope is dissected by several canyons in the Mediterranean Sea (from 180 to $2000 \mathrm{~m}$ ). Seventeen were taken into account in this study, as was the open slope between the Toulon and Stoechades canyons (Fig. 1).

Water circulation is generally westward along the continental slope and is constrained by two dominant winds: north-northwesterly winds (upwelling favourable winds) and southeasterly winds (downwelling favourable winds). Prevailing winds from north-west to west (Mistral) cause the displacement of warm surface waters to the open sea, generating six upwelling locations in the Gulf of Lion (Millot, 1990). In combination with the morphology of the coast-line, the Mistral leads to the most intense upwelling of the Gulf of Lion, which rises from the Cassidaigne canyon off Marseille (Alberola and Millot, 2003). During winter, both heat loss and evaporation lead to the cooling and mixing of the coastal waters in the Gulf of Lion. These cold shallow waters finally become denser than the surrounding waters and sink, forming currents known as dense shelf water cascades (DSWC). They carry huge amounts of sediment and organic matter to the deep ocean as they scour the shelf and seafloor slope while sinking. The source area of DSWC is located off Perpignan in the Gulf of Lion (Canals et al., 2006; Durrieu de Madron et al., 2005). 


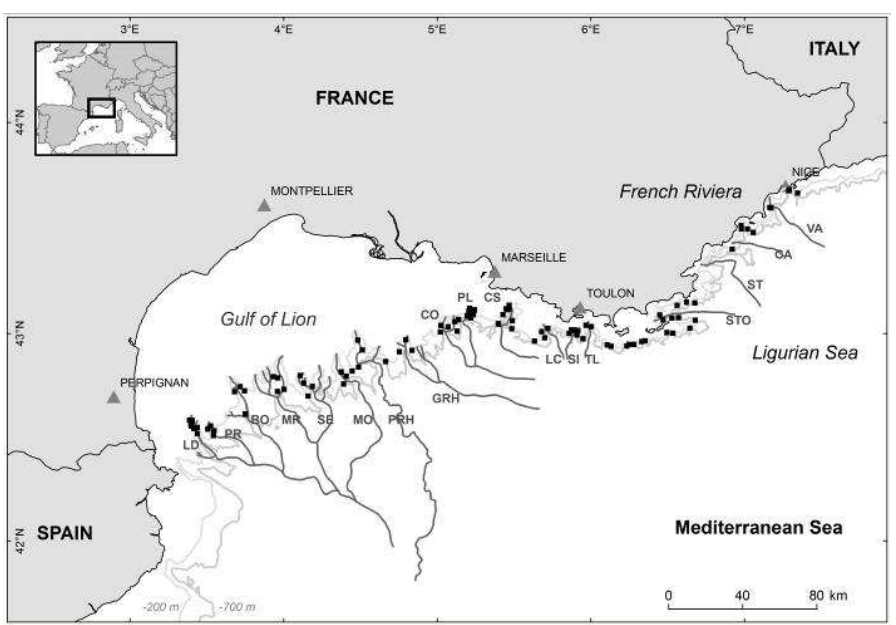

Fig. 1. The French continental margin of the Mediterranean Sea dissected by a series of submarine canyons.

From West to East: LD: Lacaze-Duthiers, PR: Pruvost, BO: Bourcart (Aude), MR: Marti (Hérault), SE: Sète, MO: Montpellier, PRH: Petit Rhône, GRH: Grand Rhône, CO: Couronne, PL: Planier, CS: Cassidaigne, LC: La Ciotat, SI: Sicié, TL: Toulon, STO: Stoechades, ST: Saint-Tropez (not considered in this study), CA: Cannes, VA: Var. Black squares represent the dives considered in this study (> $180 \mathrm{~m}$ depth) during the MEDSEACAN 2009, MARUM 2009, MARUM-Senckenberg 2011, ESSROV 2010 and CYATOX 1995 cruises.

\subsection{Data origin}

\subsubsection{New data}

Recent data were collected during the MEDSEACAN cruise organised by the "Agence des aires marines protégées" (Aamp) in 2009. The aim of the cruise was to explore the head of the canyons and so it was not specifically dedicated to the census of Vulnerable Marine Species. The data obtained from a total of 101 dives performed with the 'Super Achille' Remotely Operated Vehicle (ROV) from Comex (www.comex.com) are used for this paper (Table 1). The manned submersible 'Remora' was also deployed during the MEDSEACAN cruise, but the video films taken were not processed for this study, apart from one taken during a dive in the Bourcart canyon (BO_R2K_P1). Seventeen submarine canyons dissecting the French continental slope in the Mediterranean Sea, and the open slope between the Toulon and Stoechades canyons were explored in the bathyal bathymetric zone, from 180 to 700 meters depth (Fig. 1).

Additional video films were collected during two other cruises with the Comex team: the 2009 MARUM cruise (R/V "Minibex"; P.I. D. Hebbeln) to the Cassidaigne canyon and the 2011 MARUMSenckenberg cruise (R/V "Minibex"; P.I. S. Tesche) to the Lacaze-Duthiers canyon (Table 2). The 'Super Achille' ROV and the manned submersible 'Remora' were deployed to collect colour video films and digital images and, exceptionally, a few samples. Data from four more dives were processed qualitatively: one dive with the Ifremer manned submersible Cyana (dive 1214-03 during the cruise CYATOX in 1995 (R/V "Le Suroit"; P.I. F. Galgani) and three dives (397-01, 401-05, 407-11) with the Ifremer Victor 6000 ROV from cruise ESSROV in 2010 (R/V "Pourquoi Pas?"; P.I. P. Simeoni) (Table 2). The global bathymetric map (100 m grid) of the French Mediterranean coast was compiled at Ifremer from different cruises (Loubrieu and Satra, 2010). The detailed bathymetric map (10 m grid) of the Bourcart canyon was obtained from the Marion 2000 cruise (Berné, 2000).

\subsubsection{Historical data}

Distribution maps of several Vulnerable Marine Ecosystems were digitalized from old documents in order to complete the information gathered from submersible exploration. The 
distribution of Isidella elongata and Funiculina quadrangularis were assessed previously in the Gulf of Lion and in the Ligurian Sea by trawling (Carpine, 1964; Fredj, 1964; Maurin, 1962).

\subsection{Processing of video and navigation data}

The exploratory dives were performed by the ROV equipped with two cameras. One was fixed to a pan and tilt mount used by the pilots and recorded continuously on DVcam tapes and a hard disk recorder. The other was fixed and mounted under the first one. This camera was equipped with a zoom and could record HD images and HD video, but not continuously. The ROV navigation data were derived from the SSBL subsea positioning system, Kongsberg HPR 410, and the surface positioning system, DGPS AG132 - Trimble and Vector - Hemisphere GPS.

The distribution of communities, species and other objects and features (e.g. litter and fishing impacts) was mapped along dive tracks from video studies of each dive, using the Ifremer underwater vehicle data post-processing software "Adelie" (www.ifremer.fr/adelie) including an extension for the ArcGIS 9.3 software suite (C ESRI). The navigation files included date, time, latitude, longitude, heading and depth. All the Super Achille navigation track data had to be formatted manually in order to enter the dedicated Ifremer "Adelie" extension. The navigation data were post-processed using Gaussian smoothing. For the sake of practicality, the video films (10 minutes each) from the MEDSEACAN cruise were concatenated and encapsulated in order to obtain one video film corresponding to one dive to facilitate handling. Metadata from images captured during the Super Achille dives, like date, time and image name, were grouped manually in a distinct file in order to georeference these images via time codes within ArcGIS. Certain digital images were captured directly on board in real-time during the Super Achille dives. In addition, georeferenced minifilms were extracted with a 2 second image interval from the video films of the 2009 MARUM cruise and the 2011 MARUM-Senckenberg cruise. "Adelie" also allowed us to complete this image collection with georeferenced still images from the video films. The Geodesic system used was WGS84, in Mercator projection with standard parallel N42.

In this paper we focused on the occurrences of benthic fishes, Vulnerable Marine Ecosystems, and anthropogenic impacts located deeper than $180 \mathrm{~m}$. Dive navigation tracks that occurred above 180 $\mathrm{m}$ depth were not considered.

\subsection{Distribution of benthic megafauna species}

In order to estimate abundances along navigation tracks each individual and colony record was plotted on the GIS and represented by a point. A video still of every record was captured and georeferenced in a GIS when no digital image was available. Every specimen was identified at the lowest possible taxonomic level. However, identification at species level for some organisms from video footage was sometimes hampered due to poor video quality, high particle content in the water column and/or limited resolution for detecting morphological characteristics distinguishing similar species and had to be based on sampling. J. Vacelet (Marseille Univ.) assisted with Porifera identification, S. Sartoretto (Ifremer Toulon) and H. Zibrowius (Marseille) with cnidarian identification, E. Gramitto (ISMAR-CNR) with Actinopterygii Ophidiiformes identification, A. Souplet with Caridea identification and S. Iglesias (MNHN Paris) assisted with Actinopterygii identification.

\subsection{Distribution of substrates}

Two types of substrates could be seen in the video films: soft substrates and hard substrates. They were mapped along navigation tracks and the percentage per dive was calculated.

\subsection{Distribution of bauxite red mud deposition}

Every occurrence of red mud observed in the video films recorded in the Cassidaigne canyon was georeferenced and mapped.

\subsection{Distribution of anthropogenic litter}


In order to estimate abundances along navigation tracks, we focused on plotting occurrences of anthropogenic litter. They were classified into seven classes (metal, glass, plastic, pottery, wood, concrete, others - including fabric and paper-board) according to the method described previously (Spengler and Costa, 2008).

\subsection{Quantification and distribution of trawling impacts and lost fishing gears}

Trawling scars were counted along the navigation tracks when they were isolated and considered to be at least one meter in width. When they covered a large part of the navigation track with no possible individualization, the length of the disturbance was measured along the navigation track. Both types of trawling scar lengths were totalled and the percentage of the disturbance was calculated with regard to the total navigation track length of the dive. Lost fishing gears observed along navigation tracks were quantified and georeferenced.

\subsection{Abundances (occurrence. $\mathrm{km}^{-1}$ )}

Evaluating surface areas and thus fauna densities from the video films was not possible technically, since: (1) the parameters (zoom, pan and tilt) of the camera used to record continuously were not steady; (2) the absence of lasers on the continuously recorded camera prevented the calculation of surfaces. In addition to these technical problems, the exploratory nature of the dives inevitably influenced the navigation tracks, introducing a bias in the data. Indeed, pilots and scientists tended to follow topographic features associated with fauna, which is completely different from following a pre-determined transect dedicated to the objective sub-sampling of spatial data.

With regard to these difficulties we decided not to calculate densities but to estimate abundances along navigation tracks. Event records per dive were extracted from the GIS distribution tables and their abundance was then standardized by dividing the counts by the length of the navigation track (calculated with the GIS tools). Each abundance was then calculated as a function of a one kilometer navigation track.

\subsection{Abiotic parameters}

The length of dive tracks was calculated using the Spatial Analyst Tool from ESRI GIS. Min. and Max. depths were extracted from navigation files or read on the video records when not available or incorrect in the navigation files.

The Euclidian distance to the coast was calculated in three steps. Firstly, each navigation track was reduced to its centre of gravity. The raster of the Euclidian distance to the closest coast line was generated and converted into a point shapefile. A spatial join between the two shapefiles (navigation track and distance to the closest coast) allowed calculating the distance to the closest coast for each navigation track.

The mean slopes for every navigation track were calculated in degrees from 0 to 90 . A raster of the slopes was produced from the compiled bathymetry $(100 \mathrm{~m}$ grid) of the Mediterranean Sea (Loubrieu and Satra, 2010). Polygons were created for each navigation track line using $70 \mathrm{~m}$ width buffers and converted into a raster shape file. A zonal statistics table generated by the Spatial Analyst Tool allowed summarising the mean slope values within the zone of another dataset, in our case the navigation track polygons.

\subsection{Statistical analyses}

Biogeographical analyses were performed on VME fauna and resource abundances averaged per canyon. Cluster analysis, non-metric Multi-Dimensional Scaling (nMDS) and Principal Component Analyses (PCA) were performed using PRIMER (Plymouth Routines in Multivariate Ecological Research, Ver. 5, (Clarke and Warwick, 2001)). Vertical distribution box plots and student t-tests were performed using $\mathrm{R}$ freeware. 
We used Redundancy Analysis (RDA) in a multiple linear regression procedure in order to understand the effect of depth, slope and distance to the coast on the distribution of litter between canyons. RDA uses permutation testing to find the significance of explained variation ( $\mathrm{R}$ freeware).
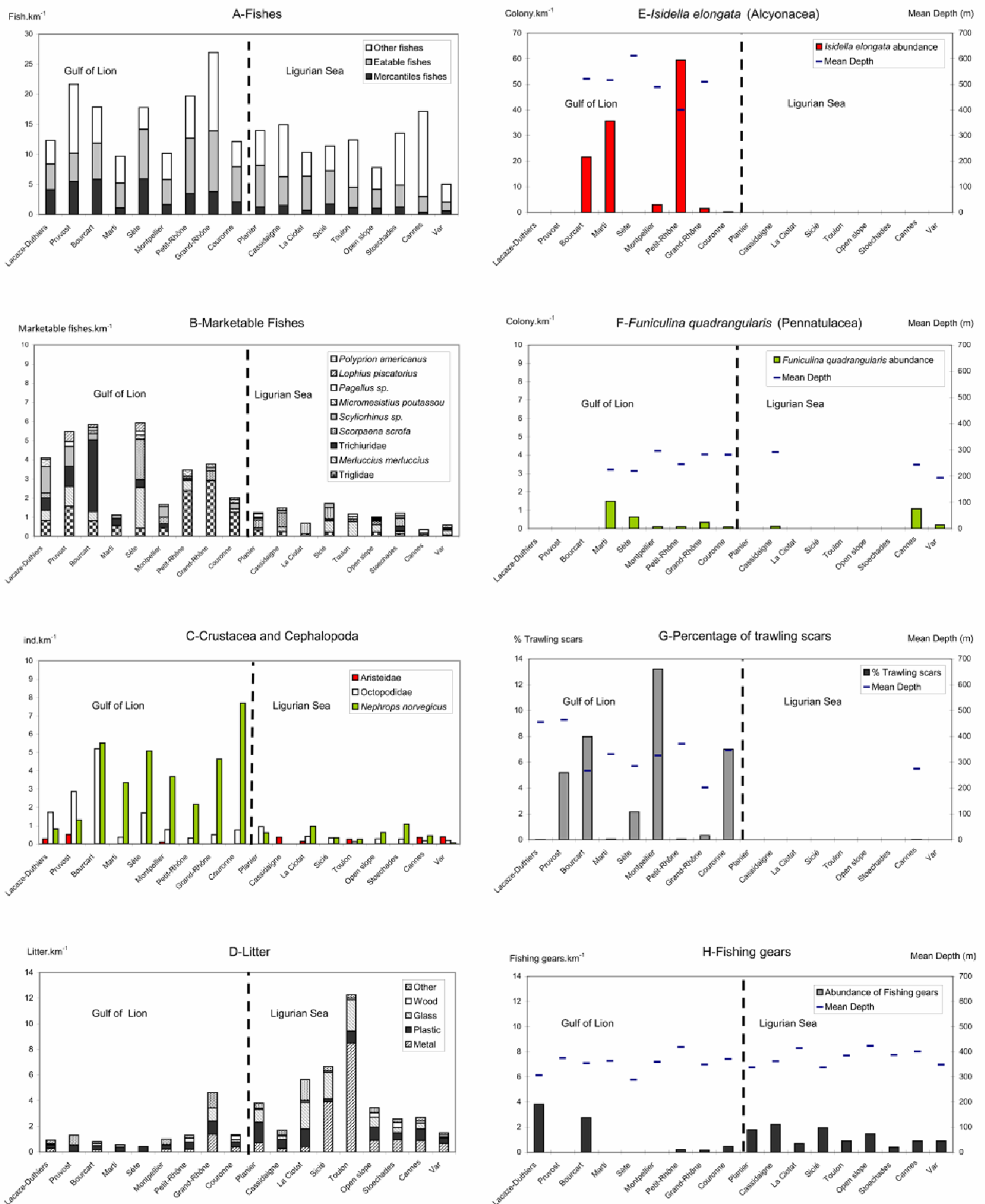

Fig. 2: Histograms of abundances. to east. 


\section{Results}

\subsection{Distribution of fishing resources}

\subsubsection{Distribution and abundance of fishes observed on the seafloor}

The fish species observed on the video films recorded along dive navigation tracks were listed with their abundance and maximum depth (Table 3). At least 59 mainly benthic and demersal species were recognized.

The most abundant species was Helicolenus dactylopterus, which was also the only species observed in every canyon. Two species were observed in shoals, Trachurus sp. and Anthias anthias, which were not counted and therefore removed from the following analyses. The other abundant species (>50 records for 101 dives) were Coelorinchus caelorhincus, Phycis blennoides, Gadiculus argenteus, Capros aper, Galeus melastomus, Trigla lyra, Merluccius merluccius, Argentina sphyraena, Lepidorhombus boscii, and Scorpaena scrofa.

Co-occurrences of fish species with vulnerable sessile marine species such as Anthias anthias were observed in shoals around bushes of Madrepora oculata in the Cassidaigne canyon, and Benthocometes robustus was observed only in the close vicinity of large colonies of gorgonians (Callogorgia verticillata) and antipatharians (Leiopathes glaberrima and Antipathes cf. dichotoma) up to 1 meter long in the Bourcart and Cassidaigne canyons.

The benthic fishes observed in the video films were classified into three categories: Marketable $(\mathrm{M})$, Edible (E) and Others $(\mathrm{O})$ (Table 3). Their abundance and distribution between canyons is presented in Fig. 2A. The distribution of marketable benthic fishes was analyzed in more detail as they are targeted by fisheries and their presence leads to impacts on the bottom caused by fishing.

\subsubsection{Distribution and abundance of marketable benthic fishes}

Of the 13 marketable fish species mentioned in table 3, we kept only 9 for the analysis. Trachurus sp. and Zeus faber were removed because one is pelagic and the other is from the shelf. Scyliorhinus canicula and Scyliorhinus sp. were grouped into Scyliorhinus spp. Trigla lyra and Triglidae were grouped into Triglidae. The 9 marketable fishes considered in the study are therefore Lophius piscatorius, Merluccius merluccius, Micromesistius poutassou, Pagellus sp., Polyprion americanus, Scorpaena scrofa, Scyliorhinus sp., Trichiuridae and Triglidae.

Triglidae were the most abundant, followed by Merluccius merluccius, Trichiuridae and Scorpaena scrofa. The Gulf of Lion (from Lacaze-Duthiers to Couronne) presents higher abundances of these marketable fishes than the Ligurian Sea (Student test, $\mathrm{p}<0.0005$, variance equality), with two exceptions: the Marti and Montpellier canyons in which we observed fewer fishes (Fig. 2B).

\subsubsection{Crustacea and Cephalopoda: Nephrops norvegicus, Aristeidae and Octopodidae}

Nephrops norvegicus, a commercial crustacean, was found in every canyon explored apart from the Cassidaigne canyon (Fig. 2C). They were always observed defending their burrows against the ROV (Fig. 3A). The highest abundances were recorded in the Gulf of Lion in the Couronne canyon and Bourcart canyon. A total of 286 individuals were counted. They were located at a mean depth of $380 \mathrm{~m}(+/-51 \mathrm{~m})$.

Aristeidae, or red shrimps, were rarely observed in the videos (Fig. 3B). A total of 22 individuals were counted (Fig. 2C). They were located at a mean depth of $542 \mathrm{~m}$ (+/- $104 \mathrm{~m})$. Shrimps of the Pandalidae family could be observed in higher abundance than Aristeidae, but they are not targeted by fisheries and are bycatch species.

Octopodidae were much more frequent in the Gulf of Lion than in the Ligurian Sea (Fig. 2C). The highest abundance was recorded in the Bourcart canyon. A total of 150 individuals were observed. They were located at a mean depth of $330 \mathrm{~m} \mathrm{(+/-81} \mathrm{m).} \mathrm{Some} \mathrm{individuals} \mathrm{were} \mathrm{very} \mathrm{small,}$ only $7 \mathrm{~cm}$ (Fig. 3C). 


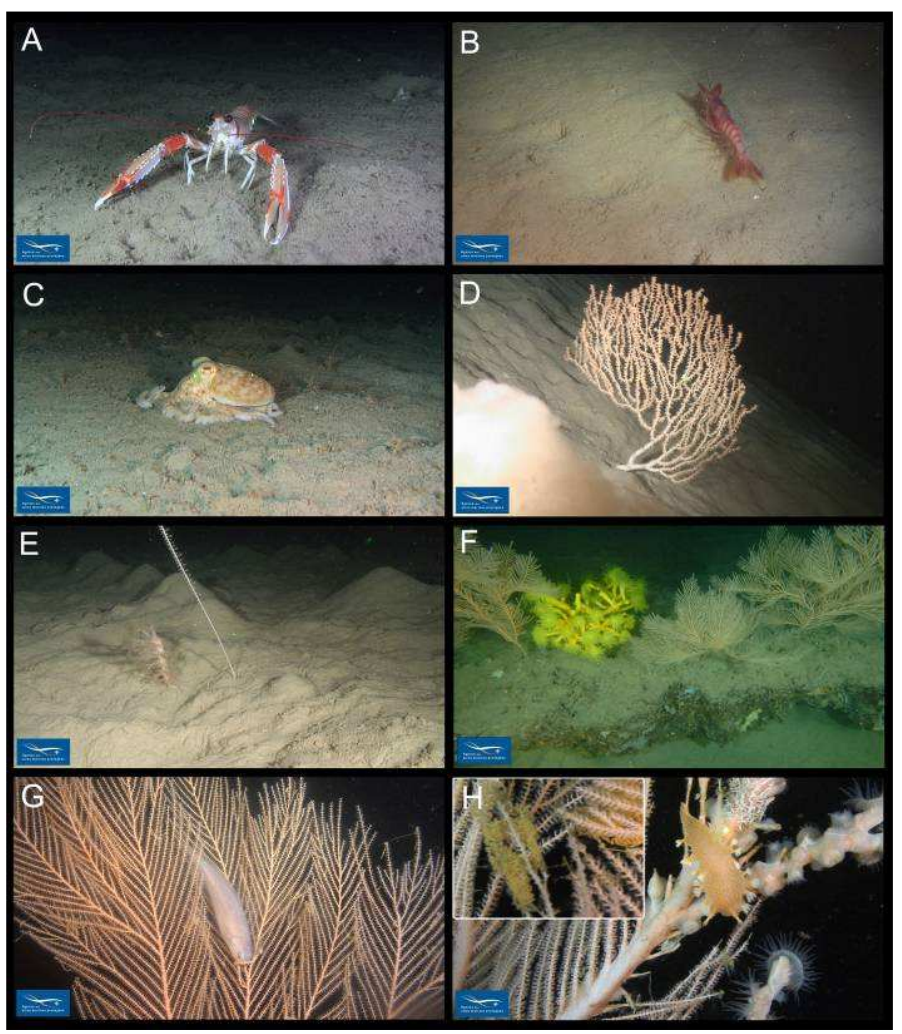

Fig. 3: MEDSEACAN cruise images of commercial resources and vulnerable marine species.

A: Nephrops norvegicus on bathyal bioturbated mud in the Planier canyon, dive P10, $395 \mathrm{~m}$. B: A red shrimp, Aristeus antennatus, on bathyal mud in the Lacaze-Duthiers canyon, dive P13, 663 m. C: An example of Octopodidae on bathyal mud in the Couronne canyon, dive P1, 226 m. D: Isidella elongata on a sloping seafloor of compact mud in the Montpellier canyon, dive P3, $573 \mathrm{~m}$. E: Funiculina quadrangularis (right) and Kophobelemnon leucharti (left) on bioturbated soft mud in the Marti canyon, dive P4, $227 \mathrm{~m}$. F: Large colonies of Callogorgia verticillata and Dendrophyllia cornigera on a rocky slab in the Boucart canyon, dive BO_R2K_P1, $350 \mathrm{~m}$. G: The Ophidiidae Benthocometes robustus hiding in a $C$. verticillata colony in the Bourcart canyon, dive BO_R2K_P1, $350 \mathrm{~m}$. H: Nudibranchia Tritoniidae and the parasitic zoanthid Isozoanthus primnoidus living on a colony of $C$. verticillata; insert: detail of Tritoniidae eggs in the Sicié Canyon, dive P4, $261 \mathrm{~m}$.

\subsection{Distribution of Vulnerable Marine Ecosystems}

\subsubsection{Distribution and abundance of Isidella elongata communities observed on bathyal mud}

Isidella elongata colonies were observed in the Gulf of Lion during the MEDSEACAN cruise. They were found in higher abundance in three canyons: Bourcart (dive P5), Marti (P1 and P5), and Petit-Rhône (P3, P4 and P5) (Fig. 2E). A total of 913 colonies were counted. They were located at a mean depth of $459 \mathrm{~m}(+/-84 \mathrm{~m})$.

In the Bourcart canyon, colonies were observed between two gullies on the west flank (P5), with equal proportions of small $(10 / 20 \mathrm{~cm})$ and medium/large $(40 / 60 \mathrm{~cm})$ colonies. Trawling scars were also seen in this canyon, located on the other flank (P6).

In the two other canyons (Marti and Petit-Rhône) no trawling scars were seen where two meadows of I. elongata were present on sloping seafloor (about 10 to $20^{\circ}$ ) (Greene and Bizzarro, 2007). In the Marti canyon, all the colonies were small (20 to $30 \mathrm{~cm}$ high), while in the Petit-Rhône canyon (P5) large $(60 \mathrm{~cm})$ and small colonies $(10 / 20 \mathrm{~cm})$ could be observed close together, standing and healthy (Fig. 3D). 
A few other colonies were observed in lower abundance in four canyons: Montpellier, GrandRhône, Couronne and Cassidaigne (one live colony and three dead ones in upright position, smothered with the red mud, MARUM 2009 cruise, dive D3).

The mud on which I. elongata colonies were established presented small domes or tumuli and holes, indicating a high level of bioturbation, mainly due to crustaceans. Many of these could be seen in the videos, including some Galathoidea (Munida sp.), Caridea (Plesionika sp.) and Axiidea (Calocaris macandreae), though the majority was made up of Nephropidae (Nephrops norvegicus). I. elongata was usually located on sloping seafloors (about 10 to $20^{\circ}$ ).

\subsubsection{Distribution of Funiculina quadrangularis communities on bathyal mud}

The highest abundance of $F$. quadrangularis was observed in the Marti canyon and in the Cannes canyon (Fig. 2F). A total of 32 colonies were observed at a mean depth of $239 \mathrm{~m}(+/-31 \mathrm{~m})$.

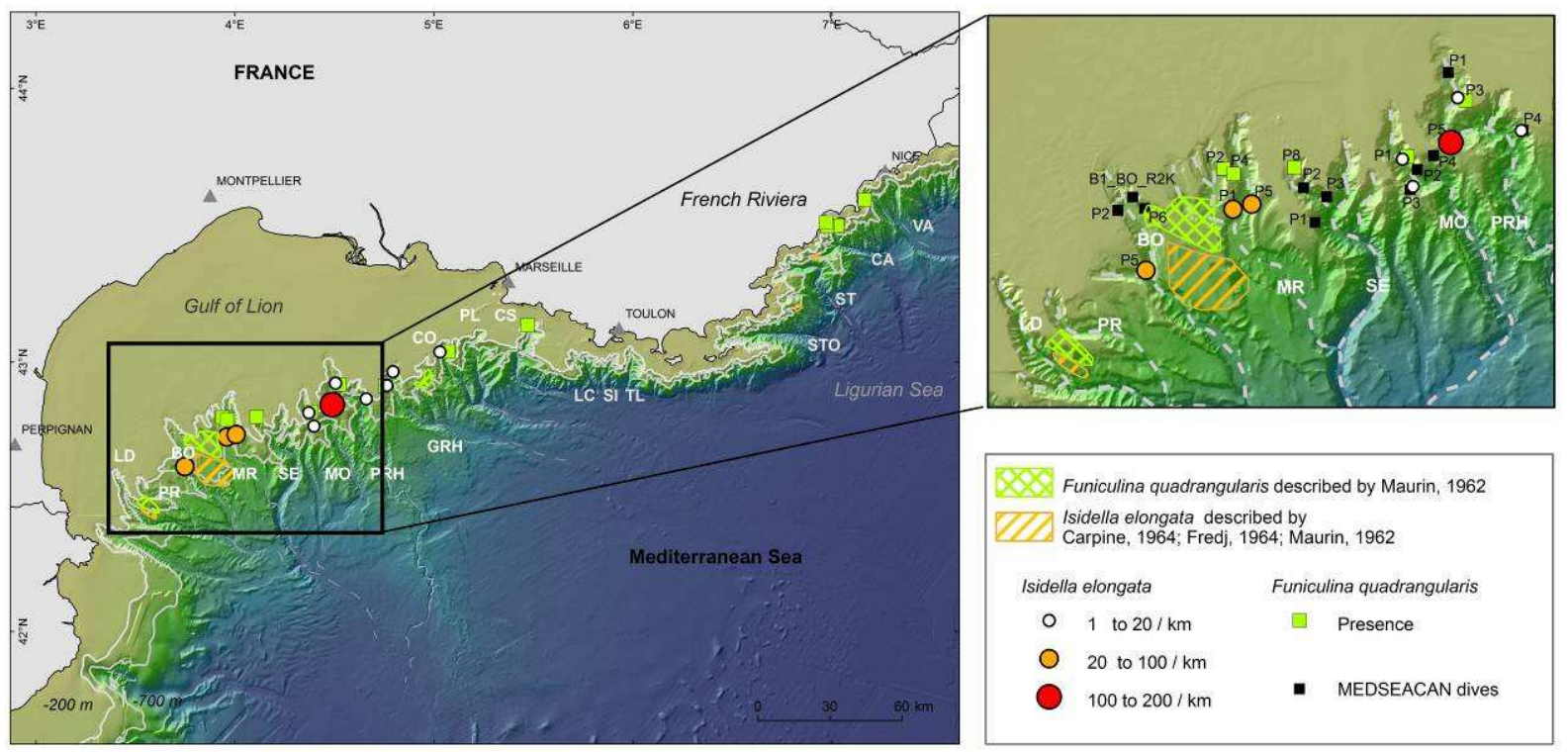

Fig. 4: Distribution of Isidella elongata and Funiculina quadrangularis observed during the MEDSEACAN dives in French canyons and as described by Maurin, 1962, Carpine, 1964 and Fredj, 1964.

Submarine canyons from West to East: LD: Lacaze-Duthiers, PR: Pruvost, BO: Bourcart (Aude), MR: Marti (Hérault), SE: Sète, MO: Montpellier, PRH: Petit Rhône, GRH: Grand Rhône, CO: Couronne, PL: Planier, CS: Cassidaigne, LC: La Ciotat, SI: Sicié, TL: Toulon, STO: Stoechades, ST: Saint-Tropez (not considered in this study), CA: Cannes, VA: Var.

\subsubsection{Distribution of Callogorgia verticillata communities observed on hard substratum}

The highest abundance was found in the Bourcart canyon (Dive _R2K_P1), followed by the Cassidaigne (P7, MARUM D2, D9), Planier (P8 and P11), Sicié (P4), Toulon (P4 and P5) canyons and on the open slope between Toulon and Stoechades (PO_P5) (Fig. 5). A total of 452 colonies were observed at a mean depth of $360 \mathrm{~m}(+/-60 \mathrm{~m})$.

In the Bourcart canyon we observed an exceptionally high density of the Primnoidae $C$. verticillata (Fig. 3F). The colonies were encountered on the eastern flank of the canyon, during the MEDSEACAN cruise dive BO_R2K_P1. About 400 colonies were seen forming a 900 meter line along a cornice. They were recorded by video (Fig. 5A). The cornice was a slab of hard substratum located at a depth of $350 \mathrm{~m}$ (Fig. 5B). The fan-shaped colonies were up to one meter in height and oriented perpendicular to the slope. They sheltered a high diversity of megafauna including: Porifera, Scleractinia (Dendrophyllia cornigera, Desmophyllum dianthus and Madrepora oculata), Antipatharia (Leiopathes glaberrima and Antipathes sp.), Echinodermata (Cidaris cidaris, Echinus melo and Echinus sp.), Crustacea (lobster Palinurus mauritanicus, Caridea Plesionika sp. and Galatheoidea), Mollusca (Octopodidae), Actinopterygii (Phycis blennoides, Phycis phycis, Lophius piscatorius, 
Helicolenus dactylopterus, Conger conger, Benthocometes robustus and Trichiuridae), and Holocephali Chimaeridae (Chimaera monstrosa). Three individuals of the Actinopterygii Benthocometes robustus were observed hiding in $C$. verticillata fans with their heads pointing downwards (Fig. 3G). Evidence of fishing disturbance was observed many times with bottom lines and fishing nets hooked onto the hard cornice and damaging colonies of $C$. verticillata.

The Cassidaigne canyon is a semi-enclosed basin. Outside this basin, facing the abyssal plain on the open slope, a field of C. verticillata (43 colonies) was encountered during dive P7 (Fig. 5). The colonies, found at a depth from 390 to $350 \mathrm{~m}$, were separated from each other by a distance from 3 to 4 meters. Dispersed colonies were also frequently encountered at depths of 200-294 m, specifically on rocky outcrops along spurs of the western flank of the Cassidaigne canyon (MARUM 2009 cruise, dives D2 and D9). Some live branches of a C. verticillata colony were covered by ophiuroids and crinoids, whereas on the basal stem, large aggregations of the serpulid Filograna sp. and sponges were present.

Few C. verticillata colonies were encountered in three other canyons (Planier, Sicié and Toulon) and on the open slope between Toulon and Stoechades, and always on raised slabs. Colonies were one to two meters high and accompanied by several species: pagurids, a comatulid crinoid (Antedon sp.), Scorpaena scrofa, a cnidarian (Gerardia sp.), a zoantharian (Isozoanthus primnoidus), and a tritoniid nudibranch that had laid its eggs on a gorgonian (see Fig. 3H).

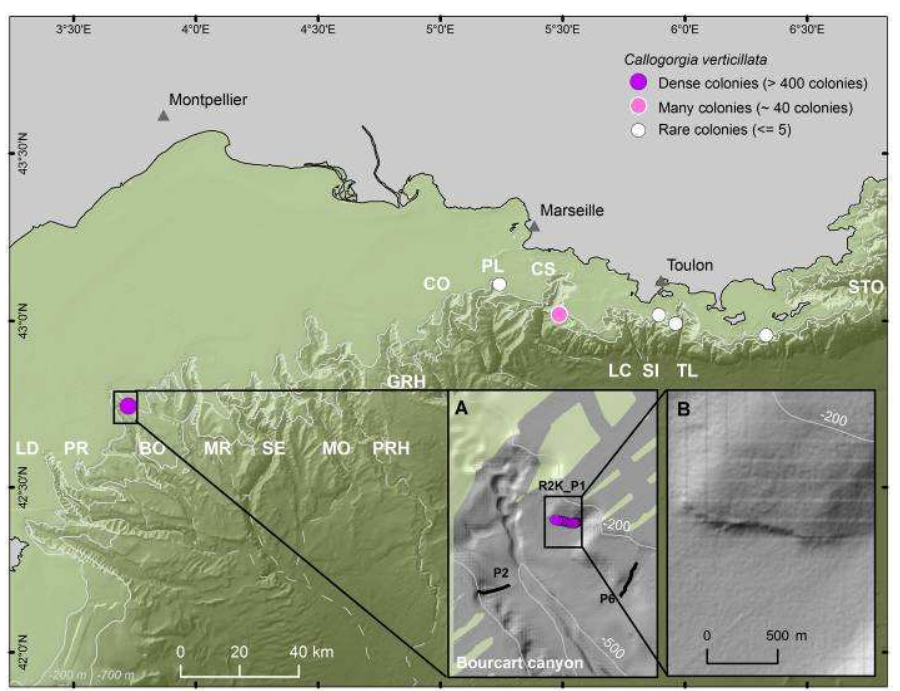

Fig. 5. Spatial distribution of Callogorgia verticillata observed during the MEDSEACAN cruise. A: Zoom on the Bourcart canyon where dive BO_R2K_P1 took place. B: Zoom on the $900 \mathrm{~m}$ long cornice of hard substratum in the Bourcart canyon (350 m depth) where colonies of $C$. verticillata were aligned (see Fig. 3F).

\subsubsection{Distribution of cold-water coral communities observed on hard substratum}

In the Mediterranean deep-sea two scleractinian species, Lophelia pertusa and Madrepora oculata, make up the dominant structure-forming corals (Fig. 6A).

The Lacaze-Duthiers canyon is the only French Mediterranean canyon where the two species $L$. pertusa and $M$. oculata have been observed living together in large quantities, the situation generally described for the biocoenosis of cold-water corals (CWC). In this canyon large colonies $(>40 \mathrm{~cm})$ of both species of scleractinians were observed at depths ranging from $246 \mathrm{~m}$ to $541 \mathrm{~m}$ at the head of the canyon and its western flank during the MEDSEACAN and MARUM-Senckenberg 2011 cruises (Fig. 7A). This canyon was highly loaded in particles, making it difficult to analyse the video films.

On the western flank of the canyon the two species of scleractinians were observed during dives P15, D2, D6 and D7 aligned on edges at depths between 340 and $350 \mathrm{~m}$. During dive P15, this edge was followed along an $800 \mathrm{~m}$ long navigation track and revealed medium-sized (20 to $40-\mathrm{cm}$ in length), downward-growing colonies of L. pertusa and M. oculata (Fig. 6B). Toward the end of the 
dive, we encountered large (>50 cm), healthy bushes of $L$. pertusa (Fig. 6C) covering an overhanging wall $10 \mathrm{~m}$ high and $20 \mathrm{~m}$ wide at $330 \mathrm{~m}$ depth on the western flank of the canyon $\left(42^{\circ} 33.677^{\prime} \mathrm{N}\right.$, $3^{\circ} 23.940^{\prime} \mathrm{E}$ ), on which many medium-sized colonies (around $20 \mathrm{~cm}$ ) of $M$. oculata co-occurred. A considerable amount of coral rubble was partially buried in the sediment lying at the bottom of this wall. M. oculata was observed without $L$. pertusa (dives P2, P11, P15 and D5) on the same flank at shallower depths ranging from 246 to $325 \mathrm{~m}$. On the same flank large, isolated bushes (> $50 \mathrm{~cm}$ ) of $L$. pertusa were observed at deeper depths ranging from 507 to $541 \mathrm{~m}$ during dive P6, while only a few isolated colonies of $M$. oculata were encountered from 376 to $531 \mathrm{~m}$ depth.

On the eastern flank of the canyon, during dive P3, another edge of hard substratum was followed along $400 \mathrm{~m}$ at about $260 \mathrm{~m}$ depth. This edge created an overhang under which a series of $M$. oculata colonies were aligned growing downward. Few L. pertusa colonies were observed on this flank (six colonies during dive P3 and one colony during dive P14) and they were partly covered with particles and epibionts. A large number of old fishing lines were tangled on the edge and in the CWC frameworks. The top of the edge was covered with a continuous layer of sediment.

A considerable diversity of CWC associated species could be seen (Fig. 6D) in the LacazeDuthiers canyon. The fishes observed were mainly Actinopterygii represented by Macrouridae (Coelorinchus caelorhincus), Moridae (Phycis blennoides), Scorpaenidae (Helicolenus dactylopterus) and Trichiuridae. Some Elasmobranchii were also present with Carchariniformes (Scyliorhinus canicula) and Squaliformes (Oxynotus centrina). Echinoidea (Cidaris cidaris, Echinus melo, Gracilechinus acutus), Scleractinia (Desmophyllum dianthus, Dendrophyllia cornigera), Bivalvia (Neopycnodonte cochlear), Porifera (Poecillastra compressa, Hamacantha falcula, and others), Crustacea (Paguroidea and Galatheidae) and Ascidiacea were numerous in these ecosystems. Some Comatulida (Leptometra phalangium) were observed on an old fishing line trapped on the bottom. No Antipatharia were observed during the dives carried out in the Lacaze-Duthiers canyon.

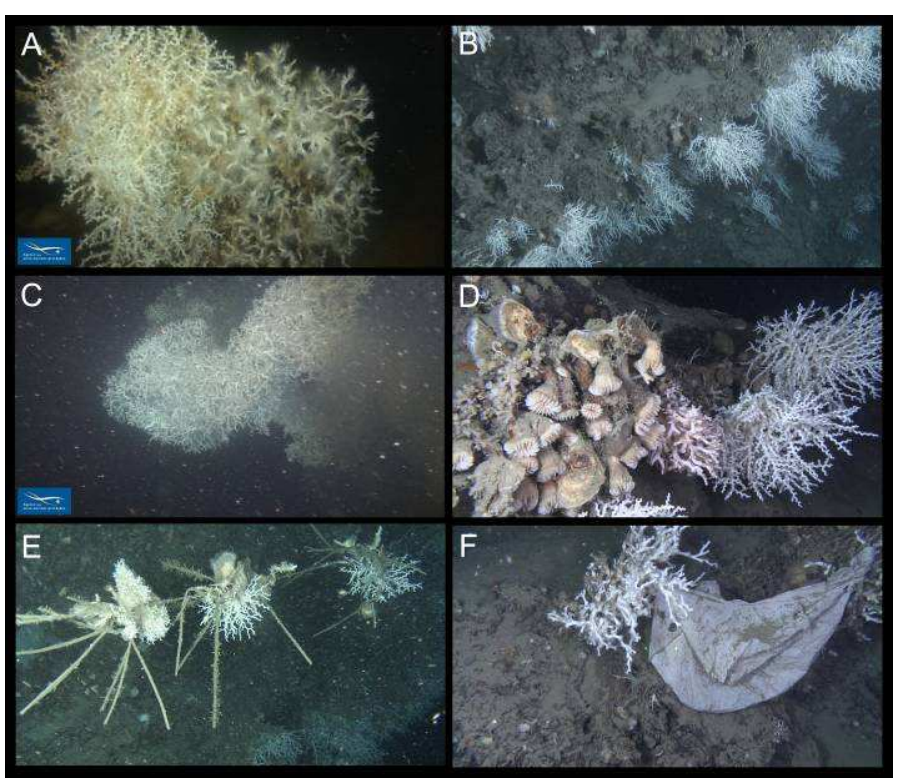

Fig. 6. Cold-water Corals in the Lacaze-Duthiers canyon.

A: Colonies of Madrepora oculata (left) and Lophelia pertusa (right), MEDSEACAN cruise, dive $P 15,369$ m. B: Colonies of M. oculata growing downward, MARUM-Senckenberg cruise, dive $D 7,342 \mathrm{~m}$. C: Large colonies of $L$. pertusa covering a vertical cliff and growing horizontally, MEDSEACAN cruise, dive P15, 343 m. D: Communities of M. oculata and L. pertusa colonies together with Desmophyllum dianthus and Neopycnodonte cochlear specimens, MARUM-Senckenberg cruise, dive D6, $387 \mathrm{~m}$. E: Lost long line under tension serving as substrate for sabellids, serpulids (amongst Filograna sp.), L. pertusa and Neopycnodonte cochlear, MARUM-Senckenberg cruise, dive D2, $331 \mathrm{~m}$. E: Soft plastics entangled in L. pertusa causing necrosis in area of contact, MARUM-Senckenberg cruise, dive $D 6,468 \mathrm{~m}$. 
The largest concentration of $M$. oculata colonies was observed on the west flank of the canyon along a crest $\left(43^{\circ} 06.76^{\prime} \mathrm{N} ; 5^{\circ} 27.62^{\prime} \mathrm{E}\right)$ during MEDSEACAN dive P1, MARUM 2009 dive D2, R1, R4 and ESSROV 2010 dive 401-05 at depths ranging from 200 to $210 \mathrm{~m}$ (Fig. 7B). At this location at the edge of the shelf, the velocity of the bottom current and the diversity were higher than what could be seen on the shelf above. The bedrock showed characteristic features of a formerly karstified landscape with dissolution holes forming cave galleries separated by pillars (Fig. 8A). The rugged topography of this karstified spur caused the loss of many fishing gears (Fig. 8B). Large bushes of $M$. oculata were observed covering the substratum whose relief was extremely rough below the overhangs (Fig. 8C). Mature M. oculata colonies attained heights up to $40 \mathrm{~cm}$. M. oculata co-occurred with many Porifera (Poecillastra compressa and others that could not be identified on the video films), Antipatharia (Leiopathes glaberrima, Antipathella subpinnata, Antipathes cf. dichotoma), Scleractinia (Dendrophyllia cornigera), Alcyoniina (Gersemia sp.), Ophiuroidea (Astrospartus mediterraneaus), Echinoidea (Cidaris cidaris, Echinus melo), Crustacea (Brachyura), Bivalvia (Spondylus gussoni) and Actinopterygii (Anthias anthias, Conger conger, Helicolenus dactylopterus). At this site at $210 \mathrm{~m}$ depth, M. oculata could be seen mixed with species from circalittoral depths, such as Holaxonia (Eunicella cavolini, Paramuricea clavata) and Scleraxonia (Corallium rubrum) (Figs. 8D and 8E).

M. oculata could be observed in red mud below $350 \mathrm{~m}$ (see 3.3.6) (Table 1 and 2) on the north face of the edge during dives 1214-03, 397-01, D5, D7, D8 and R1. 
Further south in the canyon, still on the west flank, a peculiar spot was discovered during dive $\mathrm{R} 2$. This was a vertical escarpment descending from $320 \mathrm{~m}$ depth down to at least $480 \mathrm{~m}$. The wall was colonised locally by recently settled dense colonies of $M$. oculata with very fragile branches hardly exceeding $4 \mathrm{~cm}$ in length. During dive D9, two small healthy colonies of M. oculata were observed at 324 and $244 \mathrm{~m}$ depth fixed on a vertical wall on which could also be seen colonies of Leiopathes glaberrima and Corallium rubrum.

The giant deep-sea oyster, Neopycnodonte zibrowii, was frequently encountered on (sub-) vertical flanks and overhangs of bedrock exposed in the 376-470 m depth range and appeared to be fossilised during dives D1, D7 and D9.

During the MEDSEACAN cruise, previously non reported occurrences of $M$. oculata were observed in three other canyons: Bourcart, Sicié and Var (Fig. 7, orange diamonds). In the Bourcart canyon, M. oculata was observed on a shelf of hard substratum at $331 \mathrm{~m}$ depth, during dive BO_R2K_P1 $\left(42^{\circ} 44.688 \mathrm{~N}, 3^{\circ} 42.953 \mathrm{E}\right)$. Several single branches protruded from a slab. In the Sicié canyon a $15-\mathrm{cm}$ colony of $M$. oculata was observed at $255 \mathrm{~m}$ depth $\left(43^{\circ} 0.873 \mathrm{~N}, 5^{\circ} 52.501 \mathrm{E}\right)$ while in the Var canyon, three young branches $2 \mathrm{~cm}$ long were seen growing at $350 \mathrm{~m}$ depth on a wall of hard rock $\left(43^{\circ} 35.868 \mathrm{~N}, 7^{\circ} 9.863 \mathrm{E}\right)$.

Several broken fragments of dead cold-water corals, probably M. oculata, were seen in the Planier canyon (Dive P3) (Fig. 7, black crosses) but could not be collected. They were located at the bottom of a cliff.

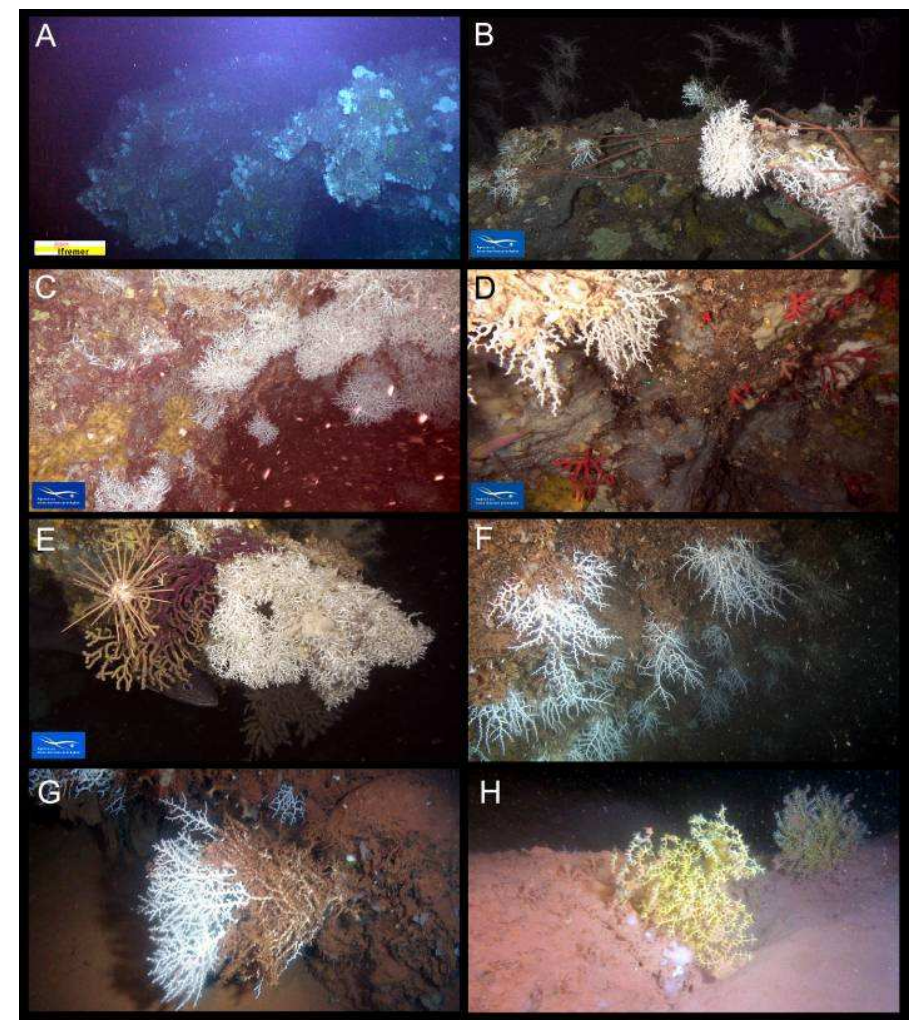

Fig. 8: Madrepora oculata and red mud deposits in the Cassidaigne canyon.

A: Characteristic features of the bedrock covered with M. oculata colonies, ESSROV 2010 cruise, dive 401-05, 238 m. B: Lost fishing gears entangled with M. oculata bushes in the Cassidaigne canyon, MEDSEACAN cruise, dive P1, $200 \mathrm{~m}$. C: Several white bushes of $M$. oculata growing downward from a rocky overhang, dive P1, 205 m. D: Red coral Corallium rubrum colonies co-occurring with $M$. oculata colonies, MEDSEACAN cruise, dive P1, $210 \mathrm{~m}$. E: High species diversity associated with M. oculata colonies: Cidaris cidaris, Paramuricea clavata and Conger conger hiding below a coral framework, MEDSEACAN cruise, dive P1, $205 \mathrm{~m}$. F: M. oculata colonies with elongated shapes and thin axes regularly spaced on a wall covered with red mud, MARUM 2009 cruise, Dive D5, 365 m. G: M. oculata colonies with 
basal portions lacking coral tissue colonised by epibionts like hydrozoans and covered with red mud, MARUM 2009 cruise, dive D7, $464 \mathrm{~m}$. H: Fan-shaped current facing colonies of Acanthogorgia hirsuta fixed on a rocky slab covered with red mud, MARUM 2009 cruise, Dive $D 1,470 \mathrm{~m}$.

\subsection{Distribution of Vulnerable Marine Ecosystem (VME) fauna and anthropogenic impacts}

\subsubsection{Distribution of trawling scars on bathyal mud}

Trawling scars were mainly located in the Gulf of Lion (Fig. 2G). We observed some large areas of sediment completely impacted (alternatively smoothed and ploughed) by repeated trawling in five canyons: Pruvost, Bourcart, Sète, Montpellier and Couronne. A highly impacted area $800 \mathrm{~m}$ long was observed in the Montpellier canyon, representing $43 \%$ of the navigation track (Fig. 13A). Trawling scars were located at a mean depth of $330 \mathrm{~m}(+/-64 \mathrm{~m})$.

\subsubsection{Analysis of the spatial distribution of resources and VME fauna on bathyal mud}

The hierarchical classification of canyons with regards to their composition in resources (marketable fishes, Nephrops norvegicus, Octopodidae) and VME fauna (Funiculina quadrangularis, Isidella elongata) on bathyal mud shows that two groups of canyons are separated at a similarity threshold of 45\%: the Gulf of Lion and the Ligurian Sea.

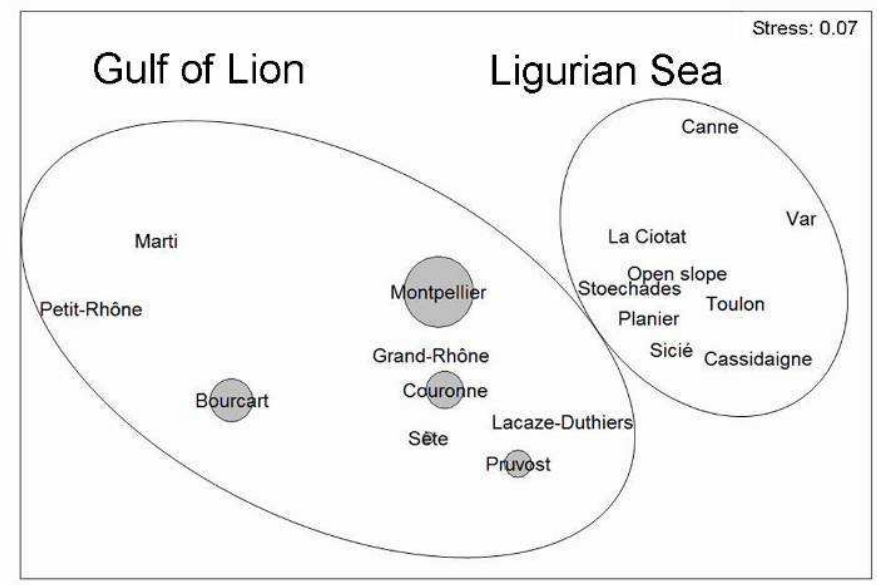

608

609

610

611

612

613

614

615

616

617

618

619

620

621

622

623

624
Fig. 9. Non metric, multi-dimensional scaling ordination of canyons. Bray-Curtis similarity coefficients of resources and VME fauna abundances were used for the ordination. Clusters formed at the $45 \%$ similarity level and trawling impact represented by circles of different sizes were superimposed on the MDS plot.

A non-metric, multidimensional scaling (nMDS) plot was produced by PRIMER (Fig. 9). A stress value of 0.07 was derived by statistical processing, indicating good ordination. A cross-check against the results of hierarchical classification was made by superimposing the groups having similarities of $45 \%$, corresponding to the Gulf of Lion and the Ligurian Sea. The superimposition of trawling scar abundances highlights the fact that bottom trawling occurs only in the canyons of the Gulf of Lion.

A Principal Component Analysis (PCA) was performed to ordinate canyons with regarding their abiotic environmental parameters that had been normalised beforehand: percentage of mud and mean slope encountered along navigation tracks. The first principal component axis explains $85 \%$ of the variance between canyons and is driven by the percentage of mud. 
The Gulf of Lion canyons are characterised by muddy substrates, while the Ligurian Sea canyons are characterised by hard substrates. The Lacaze-Duthiers canyon, which is in fact located in the Gulf of Lion, is represented in the Ligurian Sea canyons group, illustrating the high percentage of hard substrate in this canyon.

\subsubsection{Vertical distribution of resources, VME fauna and the impact of trawling on bathyal mud}

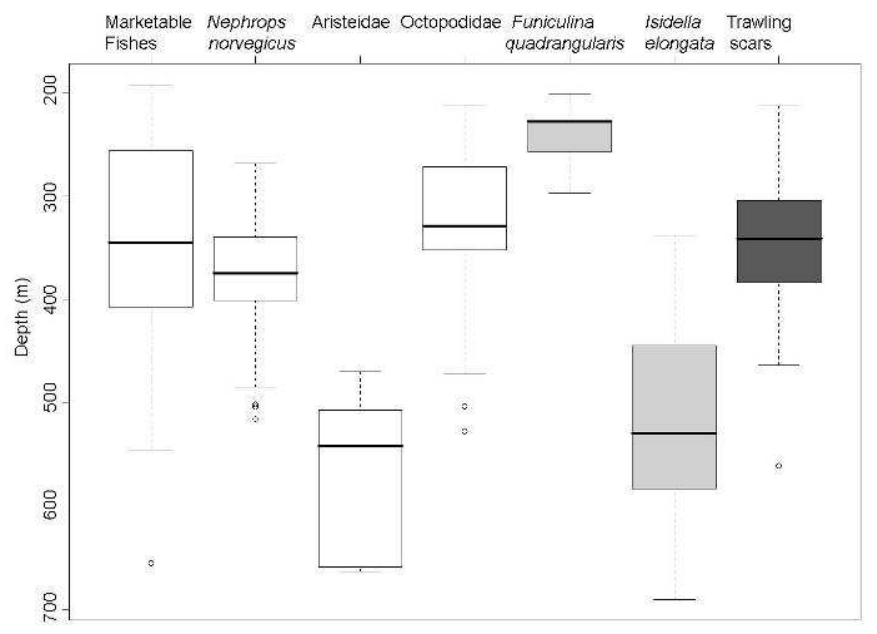

Fig. 10. Box-plot of vertical distributions in the Gulf of Lion. Resources (white), VME fauna (light grey) and trawling impact (dark grey) observed on bathyal mud in the French canyons of the Gulf of Lion during the MEDSEACAN dives.

The vertical distribution of Isidella elongata and Funiculina quadrangularis was compared to the one of resources and trawling scars in the Gulf of Lion (Fig. 10). Specimens of $F$. quadrangularis were located at shallower depths $(240 \mathrm{~m})$ than trawling scars $(355 \mathrm{~m})$ whereas specimens of I. elongata were located at deeper depths $(516 \mathrm{~m})$ (Student tests show significant differences for both, $\mathrm{p}<0.05$ ). There was no statistical difference between depth of trawling scars and resources [marketable fishes $(\mathrm{p}=0.30)$, Nephrops norvegicus $(\mathrm{p}=0.10)$ and Octopodidae $(\mathrm{p}=0.36)]$. Aristeidae were located deeper $(564 \mathrm{~m})$, in the same range as $I$. elongata $(516 \mathrm{~m})$ (Student test show no significant difference, $\mathrm{p}=0.21)$.

\subsubsection{Distribution of lost fishing gears on hard substratum}

Lost fishing gears could be observed in every canyon of the Ligurian Sea (from Planier to Var canyons) and in five canyons of the Gulf of Lion (Fig. 2H). They consisted of lost nets, lead weights and ropes, damaging structure-forming fauna and breaking cnidarian colonies. Long lines were often entangled around rocky obstacles and under tension. They formed an artificial substrate which was preferentially colonised by sabellid and serpulid polychaetes, and occasionally by Neopycnodonte cochlear and scleractinian corals (Fig. 6E). The highest abundances were recorded in the LacazeDuthiers, Bourcart (Fig. 2H) and Cassidaigne canyons (Fig. 13B). A total of 199 lost fishing gears were counted at a mean depth of $343 \mathrm{~m}(+/-88 \mathrm{~m})$.

\subsubsection{Analysis of the vertical distribution of VME fauna and lost fishing gears on hard substratum}

The vertical distribution of Callogorgia verticillata, Lophelia pertusa and Madrepora oculata was compared to that of marketable fishes and fishing gears in the Lacaze-Duthiers, Bourcart and Cassidaigne canyons (Fig. 11). C. verticillata was located within a very narrow depth range around $340 \mathrm{~m}$. L. pertusa was found deeper than M. oculata (the Student test shows significant difference, 
$\mathrm{p}<0.05)$. There was no statistical difference between depth of fishing gears and marketable fishes $(\mathrm{p}=0.11)$ or $C$. verticillata $(\mathrm{p}<0.05)$. On the contrary, fishing gears, L. pertusa and M. oculata were found at different mean depths (Student tests show significant differences, $p<0.05$ ), but their bathymetric ranges overlapped.

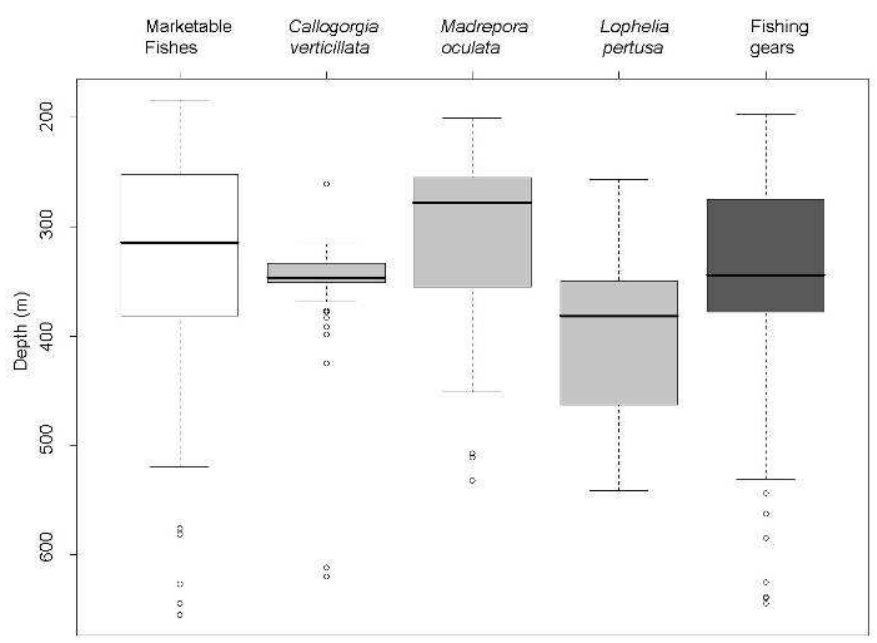

Fig. 11. Box-plot of vertical distributions in the Lacaze-Duthiers, Bourcart and Cassidaigne canyons.

Resources (white), VME fauna (light grey) and fishing gears (dark grey) observed during the MEDSEACAN dives on hard substratum in the Lacaze-Duthiers, Bourcart and Cassidaigne canyons.

\subsubsection{Distribution of cold-water coral and bauxite red mud deposits in the Cassidaigne canyon}

During all the dives in the north of the Cassidaigne canyon we observed a continuous thick layer of red mud below $350 \mathrm{~m}$ depth (Fig. 12). In the area affected by the red mud, Madrepora oculata was present in water depths from 365 to $515 \mathrm{~m}$ depth (dives D5, D7, 397-01 and 1214-03).

Dense bushes of M. oculata were recorded between 515 and $485 \mathrm{~m}$ depth (dive 1214-03) (Fig. 12) on a vertical cliff in the northern part of the western gully. A large overhang at the summit of the cliff (5 m wide) was covered with red mud. The Cyana submersible followed the edge of the overhang for 10 minutes and dense bushes of $M$. oculata could be observed growing from the edge.

In the western gully, M. oculata could be observed (D5) at $365 \mathrm{~m}$ depth on a vertical wall $5 \mathrm{~m}$ high, slightly covered with red mud. The colonies on this wall were regularly spaced, had elongated shapes with thin axes (Fig. 8F) and grew horizontally or downwards. They seemed to have settled recently. A dozen white colonies were also observed on a small rocky slab completely covered with red mud at $466 \mathrm{~m}$ depth (D7) (Fig. 8G).

Along the rocky edge at depths ranging from 300 to $390 \mathrm{~m}$, sparse bunches of M. oculata were recorded on small rocks emerging from the substrate covered with red mud (dives 397-01 and R1).

Below $350 \mathrm{~m}$ depth hard substrates were colonised by live solitary corals, including Desmophyllum dianthus and Caryophyllia calveri, with scattered to abundant frequencies and individuals measuring up to $5 \mathrm{~cm}$ in length. The upper portions and the flanks of the outcropping hard rock served as substrate for mainly fan-shaped, current-facing Acanthogorgia hirsuta colonies measuring up to $30 \mathrm{~cm}$ in length (Fig. $8 \mathrm{H}$ ). Frequently, branches of soft corals and basal portions of solitary corals were also covered with red mud. The sponge Tetrodictyum cf. tubulosum was also observed in higher abundance in this red mud environment than in other parts of this canyon. The sponge Farrea sp. was also observed at this location but nowhere else in our study. Lower in the canyon (dive 407-11) a layer of fossil bivalves (Neopycnodonte zibrowii) was observed to play the role of a hard substrate for solitary corals. Further down, at the bottom of the canyon $(725 \mathrm{~m})$, we 
found a thick layer of red mud so fluid that the ROV could not settle on the bottom to operate sampling tools (). No life could be seen on the muddy bottom.

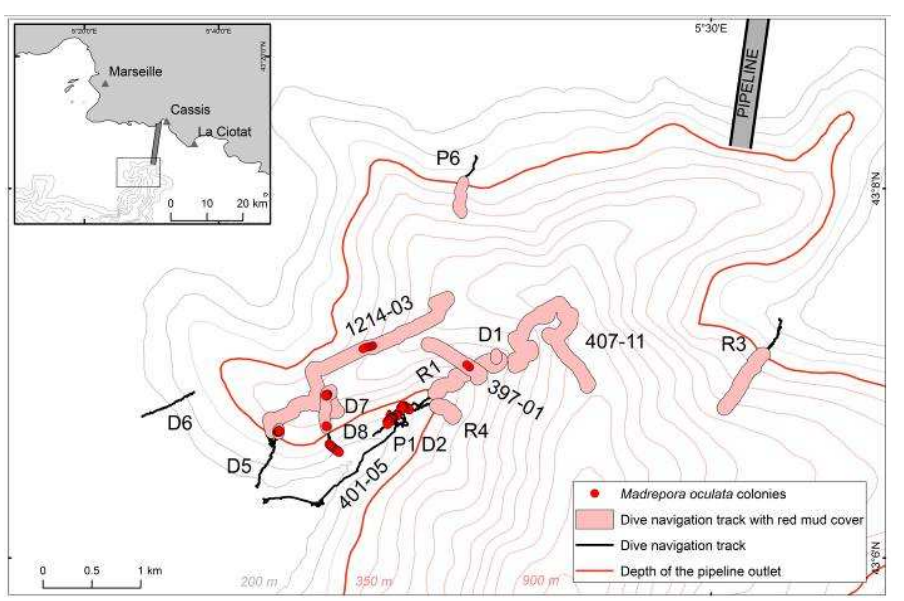

Fig. 12. Distribution map of Madrepora oculata and red mud cover observed during dives in the Cassidaigne canyon.

\subsubsection{Distribution of anthropogenic litter}

The highest abundance of litter was observed in the Toulon canyon in the Ligurian Sea (up to 12 items. $\mathrm{km}^{-1}$ ), while the highest abundance in the Gulf of Lion was observed in the Grand-Rhône canyon (up to 5 items. $\mathrm{km}^{-1}$ ) (Fig. 2D). The canyons subject to less impact were the Sète and Marti canyons in which almost no debris was observed, except for plastics (100\% in the Sète canyon) (Fig. 6F). The mean abundance was 3 items per km, 5 in the Ligurian Sea, and 1 in the Gulf of Lion.

The highest abundances of metals were found in the Toulon (9 items. $\left.\mathrm{km}^{-1}\right)$ and Sicié $\left(4\right.$ items. $\left.\mathrm{km}^{-1}\right)$ canyons (Fig. 13C). Plastics were observed in every canyon, with the highest abundance occurring in the Planier canyon $\left(2\right.$ items. $\left.\mathrm{km}^{-1}\right)$ (Fig. 13D). Glass litter was observed eastwards from the Grand-Rhône $\left(1\right.$ items. $\left.\mathrm{km}^{-1}\right)$ to the Var canyons in the Ligurian Sea, with a peak in the Toulon $\left(2\right.$ items.km $\left.{ }^{-1}\right)$, La Ciotat $\left(2\right.$ items. $\left.\mathrm{km}^{-1}\right)$ and Sicié $\left(2\right.$ items. $\left.\mathrm{km}^{-1}\right)$ canyons. Wood debris was mainly located in the Stoechades canyon $\left(0.4\right.$ items. $\left.\mathrm{km}^{-1}\right)$ and on the Open slope $\left(0.3\right.$ items. $\left.\mathrm{km}^{-1}\right)$. Concrete, ceramics and other litter (fabrics and paper-board) were grouped together because they were not represented significantly.

Redundancy Analysis in the multiple linear regression procedure detected that the "Distance to the coast" variable accounted for $17 \%$ of the variance in the distribution of litter between canyons (pvalue $=0.055)$. Mean depth, mean slope and navigation length did not provide a significant explanation of the distribution of litter between canyons.

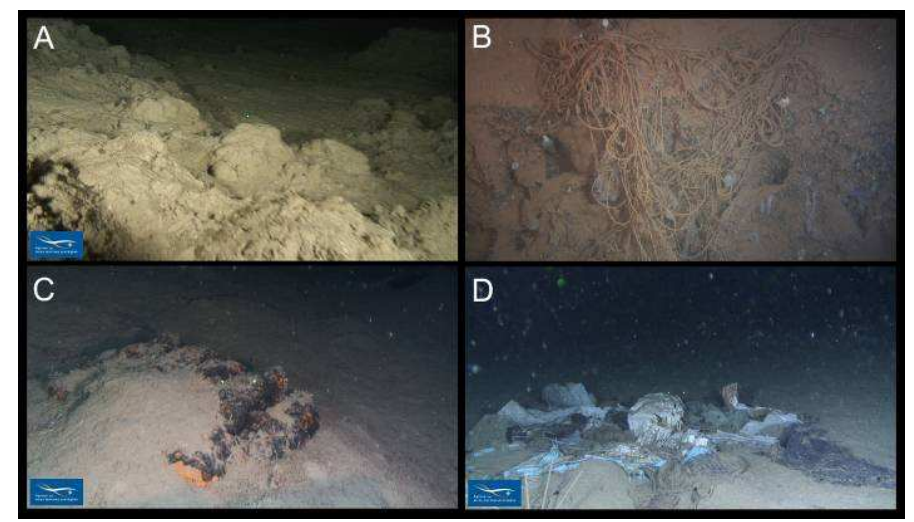

Fig. 13: Anthropogenic impacts in canyons.

A: Bathyal mud ploughed by trawling in the Montpellier canyon, MEDSEACAN cruise, dive P4, $374 \mathrm{~m}$. B: Fishing lines trapped on a rocky escarpment in the Cassidaigne canyon in an area 
of bauxite red mud sedimentation, MARUM 2009, dive D7, $465 \mathrm{~m}$. C: Metal litter (munitions) in the Toulon canyon, MEDSEACAN cruise, dive P5, $495 \mathrm{~m}$. D: Accumulation of soft plastic litter in the Planier canyon, MEDSEACAN cruise, dive $P 8,397 \mathrm{~m}$.

\section{Discussion}

\subsection{Distribution of benthic fishing resources and trawling impact}

Fishing resources (marketable fishes, crustaceans and cephalopods) were statistically more abundant in the Gulf of Lion than in the Ligurian Sea. This result further supports the well-known fact that the Gulf of Lion is an area of high productivity compared to the other parts of the Mediterranean Sea (Cartes et al., 2004). The amount of organic carbon enhancing the food chain results from the arrival of cold and fresh water from the Rhône River, bringing organic and inorganic matter from continental sources into the Gulf of Lion. The organic-matter-rich-sediment is intercepted by the heads of shelf-incising canyons and transported down-slope where it provides food to benthic ecosystems (Coll et al., 2010; Danovaro et al., 2010). Another factor that can explain the high concentration in fishing resources in the Gulf of Lion is the consequence of its large continental shelf and exposure to a cold and intense northern wind (Mistral), causing seasonal cooling and evaporation leading to the formation and downwelling of dense surface sea-water.

The benthic fishes that were recognised in the video footage of this study are those that have been frequently described on the upper slopes of the western Mediterranean Sea in previous studies in which species were sampled by trawling, as in the "MEDiterranean International Bottom Trawl Survey" (MEDITS) project (Bertrand, 2002; Cartes et al., 2002; D'Onghia et al., 2004; Demestre et al., 2000; Morfin et al., 2012). Optical imagery is a reliable tool for evaluate fish diversity, although it is not efficient for stock assessment because of difficulties in estimating spatial density and due to the escape behaviour of mobile species.

Nephrops norvegicus is a commercially important crustacean in the Mediterranean Sea. It is a sedentary marine decapod known for its burrowing behaviour and dependence on the muddy seabed sediments of the slope (Mytilineou and Sarda, 1995; Sarda, 1998). Their higher abundance in the Gulf of Lion is probably due to their preference for fine-grained sediment environments with weak hydrodynamics (Maynou and Sarda, 1997; Tully and Hillis, 1995).

Several species of Octopodidae were observed in the video films though their identification was not possible without sampling. The common octopus (Octopus vulgaris) and the horned octopus (Eledone cirrhosa) are commercially important in the Mediterranean Sea and are caught by trawling either on the continental shelf for juveniles or at greater depth for larger individuals (Sanchez et al., 2004). Octopodidae were generally located in the Gulf of Lion. The highest abundance observed in the Bourcart canyon is probably due to the rocky slab providing potential hiding and nesting places. Species living on soft bottoms are probably different from those living in a rocky environment.

We assume that most of the specimens of Aristeidae encountered might be Aristeus antennatus, which was often sampled during the MEDITS programme in the Gulf of Lion (Cau et al., 2002). Aristeidae were located deeper and in lower abundance than other resources. These depths $(<500 \mathrm{~m})$ were explored by less than half of the MEDSEACAN dives, which could explain the low abundance in Aristeidae observed in this study. Moreover Aristeidae have been observed previously down to $3000 \mathrm{~m}$ in the Balearic Islands (western Mediterranean Sea) (Cartes et al., 2009; Sarda et al., 2004). The variability in the vertical distribution of Aristeus antennatus has been proved to be correlated to the strong currents occurring during intense cascading events (DSWC) that displace individuals towards greater depths over a ten-year time-scale (Company et al., 2008).

Other shrimp, such as the bentho-pelagic species Plesionika spp., were recorded in the video films during the MEDSEACAN cruise. They were often located in high abundance in trawling scars where no other benthic species could be seen. This is explained by the fact that these opportunistic shrimp move into the trawling lane as a result of the temporary increase in food occurring due to the increased mortality of organisms following the passage of trawls (Dimech et al., 2012; Ramsay et al., 1998). 
Trawling impacts were seen to occur in the same depth-range as marketable fishes, Nephrops norvegicus and Octopodidae, which led us to assume that these species are targeted by bottom trawling. Nevertheless, as Aristeidae are probably located deeper than the area explored, we could not conclude on their "targeted species" status. In some other areas of the western Mediterranean Sea, bottom trawling targeting the deep sea shrimp Aristeus antennatus is so intense that it has modified the morphology of the sea floor above 800 m (Martín et al., 2013; Puig et al., 2012).

\subsection{Distribution of Vulnerable Marine Ecosystem (VME) and anthropogenic impacts}

Vulnerable Marine Ecosystems (VME) have been defined by OSPAR and the European Commission as being any marine ecosystem whose integrity (i.e. ecosystem structure or function) is, according to the best scientific information available and to the principle of precaution, threatened by significant adverse impacts resulting from physical contact with bottom gears in the normal course of fishing operations. Such ecosystems include, inter alia, reefs, seamounts, hydrothermal vents, coldwater corals and cold-water sponge beds. The most vulnerable ecosystems are those that are easily disturbed and whose recovery is either slow or impossible (European Commission, 2008). Bottom trawling and long lines have been shown to have dramatic effects on the structure and functioning of deep-sea ecosystems (Auster et al., 2011).

\subsubsection{Isidella elongata communities and trawling impact on bathyal mud}

We encountered few meadows of I. elongata in the Gulf of Lion (Bourcart, Marti and PetitRhône), although these communities were frequently referenced in the past in the Mediterranean Sea where they were described on the compact mud of the middle slope horizon between 500 and $1200 \mathrm{~m}$ depth (Bellan-Santini et al., 2002; Cartes et al., 2004; Peres and Picard, 1964; Relini-Orsi and Relini, 1972).

Trawling scars were always seen at shallower depths than those of I. elongata colonies. We never observed any overlap between the two vertical distributions. This led us to assume that I. elongata has been swept away by repeated trawling in the shallowest part of its natural distribution. This gorgonian species has practically disappeared from the Mediterranean Sea as it grows in areas targeted by trawling (Cartes et al., 2009; Maynou and Cartes, 2012). Deep-water gorgonian corals are known to grow slowly and live for hundreds of years (Risk et al., 2002; Williams et al., 2007), which implies a long recovery time. Anthropogenic disturbance by trawling is thus devastating for these meadows of $I$. elongata. They are considered as a sensitive habitat and efforts are being made to give them protected status (GFCM, 2009a).

The highest density of I. elongata was located on a sloping seafloor (approx. 10 to $20^{\circ}$ ) in the Petit-Rhône canyon. We assume that slopes provide protection from bottom trawling which cannot be performed on sloping seafloors. Depth also provides protection from trawling, which is limited to $1000 \mathrm{~m}$ in the Mediterranean Sea (Sacchi, 2008). The sloping seafloor and deep seabed down to $1800 \mathrm{~m}$ on which I. elongata was observed during other cruises (M-C. Fabri, pers. obs.), may act as refuge areas for this species. These refuge areas could be seen as locations where gorgonians could reproduce and disseminate. Nevertheless, no study has been conducted to assess their potential dispersion. Existing data on the growth rates of isidid octocorals are scarse but indicate slow annual growth (Andrews et al., 2009).The life span of Isididae can reach 400 years (Sherwood et al., 2009). Little is known about other important life history aspects of Isididae, such as reproduction, dispersal and colonisation patterns.

Historical data suggest that I. elongata's preferential habitat may be between gullies rather than in canyons, a characteristic we observed three times during the MEDSEACAN cruise. Large meadows of I. elongata were described in 1962 and 1964 between canyons (Carpine, 1964; Fredj, 1964; Maurin, 1962) (Fig.4). As the objective of the MEDSEACAN cruise did not focus on these areas, they should be considered as an objective for a future cruise in order to check the actual condition of these meadows and complete the present distribution of the species.

\subsubsection{Funiculina quadrangularis communities and trawling impact on bathyal mud}

We observed few $F$. quadrangularis in the video films. They were mainly located in the upper part of the explored area. This Pennatulacea is known to characterise the upper slope horizon in the 
soft muddy sediment between 180 and $400 \mathrm{~m}$ depth in the Mediterranean Sea (Bellan-Santini et al., 2002; Cartes et al., 2004; Peres and Picard, 1964).

The inability of $F$. quadrangularis to withdraw into the sediment makes it sensitive to physical disturbance (MacDonald et al., 1996). It is thought that this sea-pen has already disappeared from many trawling locations. Indeed the commercial Norway lobster Nephrops norvegicus occupies the same deep mud biotopes as Pennatulacea (Cartes et al., 2004). Trawls designed for $N$. norvegicus scrape the seabed, removing emergent epifauna and leaving it flattened. The effect of trawling on the sensitive $F$. quadrangularis makes it vulnerable. Although these Pennatulacea and their associated habitats are not directly protected by legislation they are considered to be as "sensitive" habitats worthy of conservation and more should be known about their distribution (GFCM, 2009a).

Trawling scars were always seen deeper than $F$. quadrangularis colonies. This led us to assume that either $F$. quadrangularis has been swept away by repeated trawling in the deepest part of its natural distribution, or it is located on the continental shelf as observed during the MEDITS cruise in 2012 (A. Jadaud, pers. comm.).

Historical data suggest that the preferential habitat of $F$. quadrangularis could be located between gullies rather than in canyons. Large meadows of $F$. quadrangularis were described between canyons in 1962 (Carpine, 1964; Fredj, 1964; Maurin, 1962) (Fig.4). As the objective of the MEDSEACAN cruise did not focus on these areas, they should be considered as an objective for a future cruise in order to check the actual condition of these meadows and complete the present distribution of the species.

\subsubsection{Callogorgia verticillata communities and lost fishing gears on rocky substrates}

Callogorgia verticillata is an Alcyonacea that grows to a height of $1 \mathrm{~m}$ (Bo et al., 2012). It is a suspension feeder forming large fans ( $1 \mathrm{~m}$ wide) oriented in the direction of the predominant current and mainly observed on rocky outcrops (Sanchez et al., 2009). This species is often seen associated with species of epifauna not observed in other communities, making this association unique (Ophidiiformes Benthocometes robustus, Nudibranchia Tritoniidae, zoanthid Isozoanthus primnoidus). The parasitic zoanthid Isozoanthus primnoidus (Carreiro-Silva et al., 2011) was observed on a single colony in the Sicié canyon, whereas it has been observed more frequently in the Azores (CarreiroSilva et al., 2011). This zoanthid does not appear to be a threat for gorgonians.

The Bourcart canyon holds a particularly rich population of these colonies on a 900 meter long cornice. This cornice was irregularly shaped as if covered by biogenic concretions, probably formed when the level of the Mediterranean Sea was lower during the last glaciation period (Berné et al., 1999; Lofi et al., 2003).

The high density of $C$. verticillata in the Bourcart canyon is unusual in the Mediterranean Sea and has never been reported before. Many colonies of $C$. verticillata were entangled in bottom lines and fishing nets. This led us to assume that the high diversity sheltered by the structure-forming gorgonians is attractive for local fisheries even if the area is located far from the coast $(60 \mathrm{~km})$. In the French canyons their recorded living depth, generally located around $350 \mathrm{~m}$, is targeted by bottom line fisheries.

From all these observations we propose that the fragile and poorly known $C$. verticillata should be considered as a sensitive species deserving interest and protection. These $C$. verticillata colonies have also been reported to be damaged by fishing activities on the continental shelf in the Tyrrhenian Sea (Bo et al., 2012).

\subsubsection{Cold-water coral distribution}

The CWC populations in both the Lacaze-Duthiers and Cassidaigne canyons were visited during the cruises described in this study. As previously known (Reyss, 1970; Zibrowius, 2003) the two scleractinian species Lophelia pertusa and Madrepora oculata were present in the LacazeDuthiers canyon (with M. oculata dominating over L. pertusa) while the single species M. oculata was present in the Cassidaigne canyon.

In the Lacaze-Duthiers canyon, the largest colonies ( $>50 \mathrm{~cm}$ ) of $L$. pertusa were observed along its western flank at two deep locations ( $350 \mathrm{~m}$ and $541 \mathrm{~m}$ depth), whereas colonies of $M$. oculata were located on both flanks at shallower depths ( 246 to $531 \mathrm{~m}$ on the west flank; $260 \mathrm{~m}$ on the east flank). The difference between the bathymetrical distribution pattern of $L$. pertusa and M. oculata could be 
explained by the lower tolerance of $L$. pertusa to temperature variations, since it is known that they are exposed to their maximal thermal limit in the Mediterranean Sea (Gori et al., 2013). To explain the preferential distribution of the $L$. pertusa and $M$. oculata colonies on the west flank we can assume that both flanks of the Lacaze-Duthiers canyon have different erosion regimes due to strong dense shelf water cascading on this side of the Gulf of Lion, which is similar to what happens in the Cap de Creus canyon (the next canyon westwards in Spanish waters). The bathymetric map (Fig. 7A) clearly shows that the east flank of the canyon exhibits a smooth morphology whereas the west flank exhibits steep slopes, probably due to an erosive regime (Orejas et al., 2009; Palanques et al., 2006). The erosive regime results in three favourable conditions for CWC settlement: (1) a periodic nutritive supply; (2) periodic washing of the sediment cover, leaving rocky outcrops available for settlement; (3) a rapid drop in temperature at depth (Puig et al., 2008). Colonies were oriented horizontally or downwards which is assumed to be a compromise between protection from the sediment flux and exposure to water flow to ensure feeding (Gori et al., 2013).

The Cassidaigne canyon is the other location for dense populations of scleractinian corals and sponges in the French Mediterranean Sea. The CWC community is exclusively located on the western flank of the canyon. Due to the prevailing westerly shelf currents, the eastern flank of the Cassidaigne canyon presents a prevalence of mud sediment draped over the bedrock, whereas the bedrock of the opposing western flank is much more exposed and characterised by spurs, terraced rock ledges, karstic dissolution features of former low sea-levels (e.g., the Messinian Salinity Crisis) and escarpments. The broad canyon head is fed by three tributary gullies and two spurs on both the eastern and western flanks form a bottleneck for the strong up- and downwelling hydrodynamic regime observed. On the western spur high diversity was observed with a combination of species from the shelf and from the CWC community. Mature M. oculata colonies grew mostly on the flanks of exposed bedrock. Small colonies of $M$. oculata were observed covering vertical walls at two locations at $360 \mathrm{~m}$ and around $450 \mathrm{~m}$ depth. They were considered as on-going and active settlement events in the Cassidaigne canyon.

We observed a high diversity of associated species in the Cassidaigne canyon. Deep occurrences of Corallium rubrum colonies were recorded living together with $M$. oculata colonies on the undersides of rock ledges or cave roofs from 200 to $325 \mathrm{~m}$ depth. This co-occurrence has been described recently in the Sicilian Channel at $458 \mathrm{~m}$ depth off Malta and at $673 \mathrm{~m}$ in the Linosa Trough (Costantini et al., 2010; Freiwald et al., 2009). Four species of Antipatharia (Leiopathes glaberrima, Parantipathes larix, Antipathella subpinnata and Antipathes cf. dichotoma) were also present in high abundance whereas they were not observed in the Lacaze-Duthiers canyon. This could be explained by the heavy load of suspended particles observed in the Lacaze-Duthiers canyon associated with a strong current that would be detrimental to the soft tissues of antipatharians (Wagner et al., 2012).

During the past decade, knowledge on live CWC communities in the Mediterranean Sea supported by L. pertusa, M. oculata and to a lesser degree by Dendrophyllia cornigera has increased considerably. Major coral hotspot areas are now known (Fink et al., 2013; Freiwald et al., 2009). The two CWC locations described in this paper are different from each other. The Lacaze-Duthiers CWC location is heavily loaded in particles and associated species are different from those in the Cassidaigne canyon. The latter is one of the shallowest locations ( $210 \mathrm{~m}$ depth) together with the Strait of Gibraltar (150 m depth, (Alvarez-Perez et al., 2005; De Mol et al., 2012) in which CWCs have been found. The Lacaze-Duthiers canyon is geographically close and similar in composition to the CWC community in the Cap de Creus canyon (Gori et al., 2013; Orejas et al., 2009).

The structure-forming CWC scleractinians of the Mediterranean Sea have been described to live mostly on vertical walls (this study, (Freiwald et al., 2009). They have also been described on vertical structures in the Atlantic canyons but to a greater extent, e.g., Whittard canyon, Bay of Biscay (Huvenne et al., 2011). In the Mediterranean Sea, CWC communities are never as large as those found in the Atlantic Ocean, where the prevailing conditions are more favourable with water temperatures around $4{ }^{\circ} \mathrm{C}$ and salinities around 35, whereas the Mediterranean Sea is a relatively warm (up to $13.8^{\circ} \mathrm{C}$ ) and salty basin (salinity as high as 39 ). According to current knowledge of the temperature limits for CWC, the Mediterranean Sea is close to the upper limit of many CWC occurring in the bathyal zone $\left(25.5^{\circ} \mathrm{C}\right.$ for $M$. oculata in the Indian Ocean and $14.7^{\circ} \mathrm{C}$ for $L$. pertusa in the Atlantic Ocean) (Keller and Os'kina, 2008). 
Lost fishing gears were observed in high densities together with CWC communities in both the Lacaze-Duthiers and Cassidaigne canyons. This evidence of severe pressure from fishing shows that these ecosystems therefore act as habitats for fishing resources as CWC communities are three dimensional frameworks harbouring high diversity and a rich trophic network.

Long lines and ropes entangling colonies of CWC were evidence of this fishing pressure, but these fishing gears represent only a percentage of the total effect of fishing on these CWC communities as we assume that fishing equipment is not frequently lost. Nevertheless these threedimensional structures may be broken without any loss of equipment, as shown by the detached colonies laying on the seafloor. Moreover scleractinians and associated species may be by-catch for bottom long line fishing, therefore leaving no evidence (Sampaio et al., 2012).

In order to quantify the impact of fishing on hard substratum communities, account must be taken not only of lost fishing gears but also of detached colonies. However, the detached colonies may either be the result of the fishing pressure or due to their natural growth process. Indeed, the old basal parts were infested by fixo-sessile communities (sponges, polychaetes, Neopycnodonte cochlear, Desmophyllum dianthus) and excavated by bioeroding endobionts (Beuck et al., 2010), making them fragile and heavier, finally causing them to fall. We can also add another impact caused by scientific underwater vehicles which can encounter navigation difficulties in these complex environments, resulting in breaking these luxuriant and fragile colonies.

\subsubsection{Cold-water coral and bauxite red mud disposal}

The Cassidaigne canyon is considerably affected by the massive disposal of bauxite residues (Dauvin, 2010). These red residues are expelled by an aluminium company (operated successively by Pechiney, Alcan, Rio Tinto, Alteo) located $40 \mathrm{~km}$ inland at Gardanne (Bouches-du-Rhône, France). From 1967 to 1988, this red mud was discharged through two pipelines from two separate factories at $320 \mathrm{~m}$ depth near the canyon head. Since 1988, one of the factories stopped production and ceased using one of the pipelines, resulting in the reduction of the discharge of red mud. For more than 45 years, this mud has spread along the canyon, on the lateral flanks and down to the abyssal plain, contaminating the seabed with excess iron, titanium, vanadium and chromium (Fontanier et al., 2012).

Our visual inspection of the potential impact of the red mud on the benthic megafauna underpins a selective negative if not potentially lethal effect, as the megafauna diversity observed in 2009 was lower than that observed in 1971 (Bourcier and Zibrowius, 1973). Moreover colonies of gorgonians (Acanthogorgia hirsuta) were smothered with red mud and generally showed clear signs of tissue necrosis and patches of mud flocs. Frequently, basal portions of cnidarians were covered by red mud, although living parts were very clean, suggesting an effective mechanism against high sedimentation rates.

The entire seabed along the canyon axis was covered by red mud below $350 \mathrm{~m}$ depth. The red mud also draped steep inclined rock exposures and was found underneath overhangs. The episodically severe up- and downwelling current regimes may be the driving force for the complete spatial coverage of the natural seabed by man-made discharges. The burial of the rocky substrates suitable for the settlement of Madrepora oculata prevent them from expanding deeper than $350 \mathrm{~m}$. The few $M$. oculata colonies observed deeper on blocks rising from the red mud bottom probably settled before the start of the disposal of the red mud. The highest abundances of $M$. oculata in the red mud environment were always observed on vertical walls where colonies were partly sheltered from silting. These colonies seemed to cope with the heavy sedimentation load but at a metabolic cost that remains to be investigated. However, it may point to a specific stress tolerance of M. oculata.

The recently settled colonies may be a positive result of the decrease in the red mud outflow since 1988. The objective to stop the outflow by 2015 would certainly help these protected species to survive.

\subsection{Distribution of anthropogenic litter}

The economic impact of tourism, fishing and coastal urban populations has been demonstrated to be important in the north western Mediterranean sea, where different types of debris were found on the deep sea floor (Galgani et al., 1996). It was shown that only small amounts of debris were 
collected on the continental shelf from the Gulf of Lion whereas most of the debris was found in deeper areas, mainly in zones with high sedimentation rates such as submarine canyons. In our MEDSEACAN study, higher concentrations of litter were observed in the Ligurian Sea than in the Gulf of Lion. This is linked to the narrow continental shelf in this area, with more coastal canyons. This is also related to the general circulation of the water flowing to the south in the Gulf of Lion as a consequence of both strong Northwest winds and the very considerable discharge of the Rhone River. The highest concentrations of metal objects observed in both the Toulon and Sicié canyons were explained by the presence of a large military harbour with discarded equipment on the adjacent sea floor, including weapons and ammunition. Plastics were found everywhere, with a percentage to total debris up to 100 in the Sète canyon, but in low abundance, within the same range as that described previously (Barnes et al., 2009; Galgani et al., 2000; Mordecai et al., 2011; Ramirez-Llodra et al., 2011). Pieces of glass, mainly beer bottles, were observed in the Ligurian Sea and linked to both pleasure boats and cruising ships. The Stoechades canyon contained quantities of wood debris coming from adjacent woods and forests from the three islands of Port-Cros, Porquerolles and Levant. Fishing-related objects were found in coastal canyons only, as a consequence of fishing activity. Finally, ceramics and other litter were spread everywhere but only in small quantities.

As mentioned previously (Galgani et al., 1996) debris in rocky environments cannot be evaluated by trawling. Video recording is therefore a valuable approach for evaluating litter which is often trapped in the rocky areas such as slopes. The mean concentration of litter calculated from submersible (Cyana) dives at the bottom of canyons were 24 items. $\mathrm{km}^{-1}$ (Galgani et al., 1996) on average, while the mean concentration measured on slopes in this study was 3 items. $\mathrm{km}^{-1}$, which is far less. From both studies, it is clear that the amount of litter should not be considered as decreasing with time. We link this typical situation to several causes: (1) we explored the flanks of the canyons during the MEDSEACAN cruise on which the litter does not tend to accumulate; (2) the intensity of the light and the small area covered by the camera used with a small ROV such as Super Achille are respectively lower and narrower ( 1 meter in width) than with the manned submersible Cyana. The latter enabled surveying a strip 4-5 meters wide on soft bottoms. Overall, the analysis of results provides more detailed information on the diversity of debris typically related to coastal activities including fishing, harbours and tourism.

\subsection{Vulnerable Marine Ecosystems and their preservation}

Different international organisations (International Council for the Exploration of the Sea ICES, United Nations, European Commission, General Fisheries Commission for the Mediterranean GFCM) and Conventions (OSPAR, CITES and Barcelona convention) have recommended protection and management of a list of species and habitats that are either "sensitive", "vulnerable", "threatened" or "in decline", among which some are found in deep-sea ecosystems. All these conventions have led to the establishment of Marine Protected Areas (MPA) in all the world's oceans. Three MPAs and one fishing area with restricted access have been created recently in the French part of the Mediterranean Sea (Fig. 14).

The "Parc Marin du Golfe du Lion" (decree 2011-1269) includes CWC communities of the Lacaze-Duthiers canyon and Isidella elongata communities of the Bourcart canyon. This park should implement new regulations to protect these areas against bottom fishing which is the most direct and the most noticeable threat to these ecosystems. Another specific site to be protected in this park is the rocky slab in the Bourcart canyon with high diversity associated with Callogorgia verticillata colonies.

The "Parc National des Calanques" (decree 2012-507) including the CWC communities of Cassidaigne canyon has defined several areas with specific regulations. Two of them are delimited on the western flank of Cassidaigne canyon: a "reinforced protection zone" and a "no-take zone". The "reinforced protection zone" is a "no-take zone" with some exceptions for local artisanal fishermen who were making their living there before the creation of the park. These two special zones have been defined to protect CWC communities from fishing. The "reinforced protection zone" allowing exceptional fishing is not located at the CWC location but at that where the disposal of red mud occurs. CWC communities are protected from fishing (long lines and nets) but not from the red mud discharged in this canyon which will cause long term disturbance even after the end of disposal. 
Contamination of the trophic chain could occur in the future when red mud disposal will stop in 2015, causing a change in environmental conditions and possibly leading to the release of heavy metals into the environment (Fontanier et al., 2012). Contamination of the trophic chain in the Cassidaigne canyon by heavy metals could lead to sanitary consequences. Based on the precautionary principle we think fishing should be completely prohibited in Cassidaigne canyon. New studies will be launched to study this potential contamination by heavy metals.

The "Parc National de Port-Cros" (decree 2012-649) has been recently extended to include the adjacent bathyal seafloor, where we referenced no vulnerable ecosystems.

Additionally, the Scientific Advisory Committee of the GFCM has set up a fishing area with restricted access off the French coast in the Gulf of Lion, in which the fishing effort shall not exceed the level of fishing effort applied in 2008 (GFCM, 2009b). This area includes the Montpellier, PetitRhône and Grand-Rhône canyons and has been designated as a refuge from trawling for a nonexploited spawning fraction of the demersal fishing stock (Farrugio, 2012). However, this area has not been designated for the protection of sensitive ecosystems, despite the fact that the fishing effort has been limited to present levels since 2008. Nonetheless the benthic ecosystems may have been damaged already.

Vessel Monitoring System (VMS) data could be used in order to highlight areas of heavy fishing pressure. Afterwards, the data collected from these areas should be crossed with VME spatial distribution data to set up specific conservative measures.

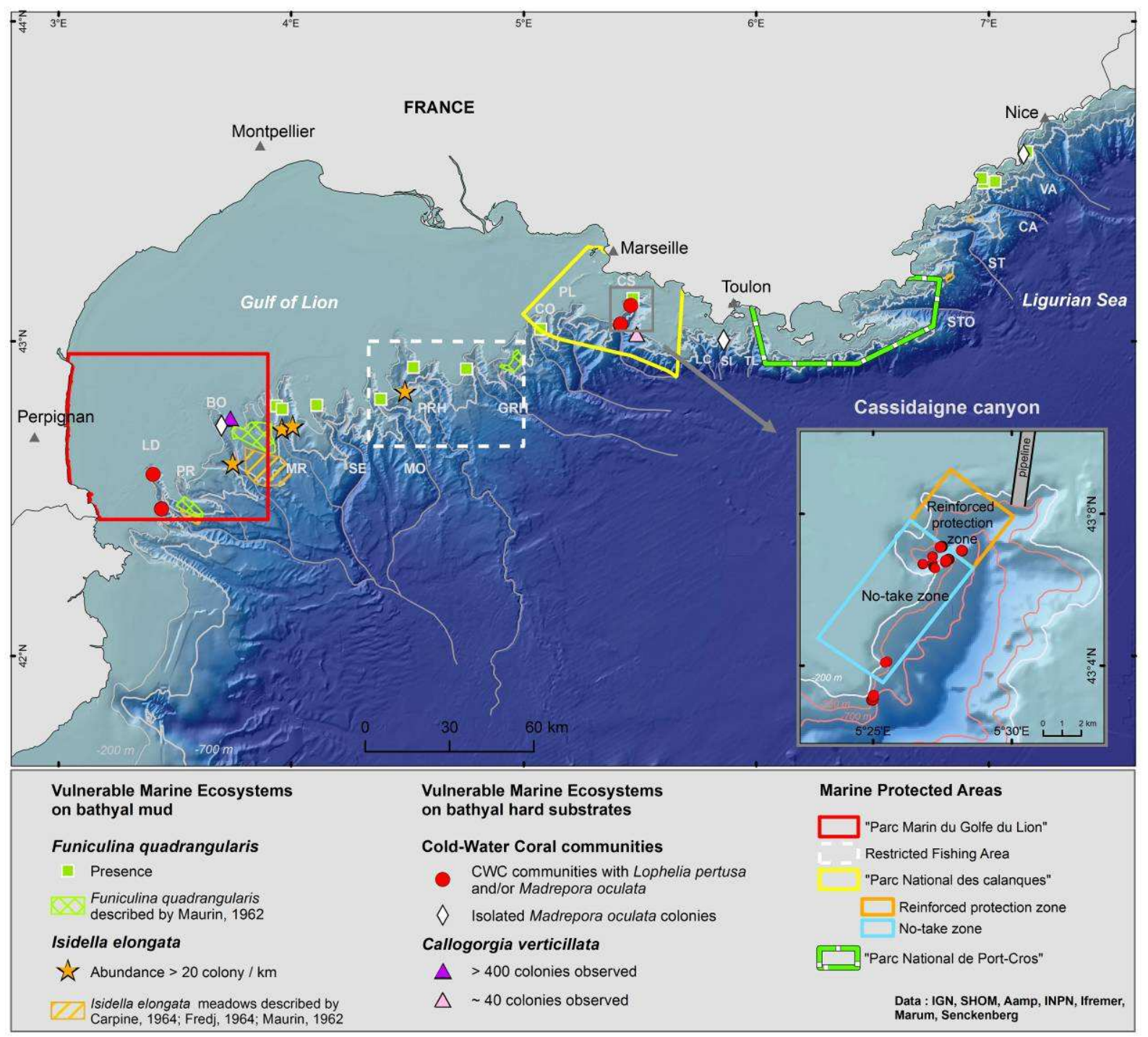


Fig. 14. Geographical localisation of the Vulnerable Marine Ecosystems and the Marine Protected Areas of the French continental coast of the Mediterranean Sea. Submarine canyons from West to East: LD: Lacaze-Duthiers, PR: Pruvost, BO: Bourcart (Aude), MR: Marti (Hérault), SE: Sète, MO: Montpellier, PRH: Petit Rhône, GRH: Grand Rhône, CO: Couronne, PL: Planier, CS: Cassidaigne, LC: La Ciotat, SI: Sicié, TL: Toulon, STO: Stoechades, ST: Saint-Tropez (not considered in this study), CA: Cannes, VA: Var.

\section{Conclusions}

Video data were used to carry out an inventory of the distributions of benthic communities in the heads of French canyons considered to be vulnerable to anthropogenic impacts. This study is the first to have enabled: (1) the comparison of 17 canyons sampled in the same bathymetrical range over a limited temporal timescale (1 year), and (2) the observation of the soft substrate of Vulnerable Marine Ecosystems (VME) in situ instead of sampling by trawling or coring.

The Canyons of the Gulf of Lion are different from those of the Ligurian Sea with regard to their abundance in resources, VME fauna, substrates and anthropogenic impacts. Soft bottom VME fauna (Isidella elongata and Funiculina quadrangularis), resources and trawling impacts were mainly located in the Gulf of Lion. These VME fauna seem to have been swept away by repeated trawling. Access to Vessel Monitoring System data could help to better evaluate fishing impacts on these communities.

Cold-water coral communities (Lophelia pertusa, Madrepora oculata) are present in two of the French canyons (Lacaze-Duthiers and Cassidaigne). Fishing and silting (e.g. red mud) are the major impacts affecting these ecosystems presenting high diversity. We propose that the community of the gorgonian Callogorgia verticillata should be considered a VME taxa as it was rarely observed, it has been severely impacted and is associated with a high species diversity.

All these VME fauna are located in the recently created Marine Protected Areas where new regulations including deep-sea ecosystem conservative measures must be drafted.

This initial assessment of VME distribution was performed using historical and recent available data. New data must be collected for the future assessment of the ecological status of benthic ecosystems to be carried out as part of the Marine Strategy Framework Directive.

\section{Acknowledgments}

We are grateful to the Agency for Marine Protected Areas (Aamp) and especially to Pierre Watremez for coordinating and organising the MEDSEACAN cruise, providing the video films and reading the manuscript. We also thank all the participants of the MEDSEACAN, MARUM 2009, MARUMSenckenberg 2011, ESSROV 2010, CYATOX 1995 cruises. The authors thank the captain, and the crew of the $R / V$ "Minibex" and the Comex team for their professionalism in operating the ROV Super Achille and Submersible Remora. Thanks are also extended to O. Soubigou, G. Clodic, B. Loubrieu from Ifremer for their help, respectively, with the "Adelie" software, video film formatting and the bathymetric surveys of the Mediterranean Sea. Furthermore we are indebted to Keith Hodson (www.accent-europe.fr) for correcting the English. The authors also thank the reviewers for their helpful comments to improve the manuscript. 
This paper was written in the framework of the Marine Strategy Directive (MSFD), with the support of the French Ministry of Ecology, Sustainable Development and Energy (convention 11/1219231/NF). $L B, D H$ and $A F$ received support from the EU-FP VII projects HERMIONE (contract number 226354) and $L B$ and AF from CoralFISH (contract number 213144).

\section{References}

Alberola, C., Millot, C., 2003. Circulation in the French Mediterranean coastal zone near Marseilles: the influence of wind and the Northern Current. Continental Shelf Research 23, 587610.10.1016/s0278-4343(03)00002-5

Alvarez-Perez, G., Busquets, P., De Mol, B., Sandoval, N.G., Canals, M., Casamor, J.L., 2005. Deepwater coral occurrences in the Strait of Gibraltar, in: Freiwald, A., Roberts, J.M. (Eds.), ColdWater Corals and Ecosystems. Springer, pp. 207-221.

Andrews, A.H., Stone, R.P., Lundstrom, C.C., DeVogelaere, A.P., 2009. Growth rate and age determination of bamboo corals from the northeastern Pacific Ocean using refined ${ }^{210} \mathrm{~Pb}$ dating. Mar. Ecol. Prog. Ser. 397, 173-185

Astraldi, M., Balopoulos, S., Candela, J., Font, J., Gacic, M., Gasparini, G.P., Manca, B., Theocharis, A., Tintore, J., 1999. The role of straits and channels in understanding the characteristics of Mediterranean circulation. Progress in Oceanography 44, 65-108.10.1016/s00796611(99)00021-x

Auster, P.J., Gjerde, K., Heupel, E., Watling, L., Grehan, A., Rogers, A.D., 2011. Definition and detection of vulnerable marine ecosystems on the high seas: problems with the "move-on" rule. ICES Journal of Marine Science: Journal du Conseil 68, 254-264.10.1093/icesjms/fsq074

Barnes, D.K.A., Galgani, F., Thompson, R.C., Barlaz, M., 2009. Accumulation and fragmentation of plastic debris in global environments. Philosophical Transactions of the Royal Society BBiological Sciences 364, 1985-1998.10.1098/rstb.2008.0205

Bellan-Santini, D., Bellan, G., Bittar, G., Harmelin, J.G., Pergent, G., 2002. Handbook for interpreting types of marine habitat for the selection of sites to be included in the national inventories of natural sites of conservation interest, UNEP Report, Tunis, p. 217.

Berné, S., 2000. Campagne Marion - Zone Bourcart, Golfe du Lion (10m). Ifremer, Plouzané.

Berné, S., Loubrieu, B., equipe Calmar, 1999. Canyons and recent sedimentary processes on the western Gulf of Lions margin. First results of the Calmar cruise. Comptes Rendus De l'Academie des sciences Serie II Fascicule a-Sciences de la Terre et des Planètes 328, 471-477

Bertrand, J.A., 2002. Mediterranean marine demersal resources: The medits international trawl survey (1994-1999) - Foreword. Scientia Marina 66, 5-7

Beuck, L., Freiwald, A., Taviani, M., 2010. Spatiotemporal bioerosion patterns in deep-water scleractinians from off Santa Maria di Leuca (Apulia, Ionian Sea). Deep-Sea Research II 57, 458-470.10.1016/j.dsr2.2009.08.019

Bo, M., Canese, S., Spaggiari, C., Pusceddu, A., Bertolino, M., Angiolillo, M., Giusti, M., Loreto, M.F., Salvati, E., Greco, S., Bavestrello, G., 2012. Deep coral oases in the South Tyrrhenian Sea. Plos One 7, e49870.10.1371/journal.pone.0049870

Bouchet, P., 2006. The magnitude of marine biodiversity, in: Duarte, C.M. (Ed.), The Exploration of Marine Biodiversity, pp. 32-64.

Bourcier, M., Zibrowius, H., 1973. Les "boues rouges" déversées dans le canyon de la Cassidaigne : Observations en soucoupe plongeante SP350 (Juin 1971) et résultats de draguages. Tethys 4, 811-842

Canals, M., Puig, P., Durrieu de Madron, X., Heussner, S., Palanques, A., Fabres, J., 2006. Flushing submarine canyons. Nature 444, 354-357.10.1038/nature05271

Carpine, C., 1964. La côte de l'Esterel, de la pointe des Lions à la pointe de l'Aiguille (Région A2) Fascicule 3. Bull. Inst. océanogr. Monaco 63, 1-52

Carreiro-Silva, M., Braga-Henriques, A., Sampaio, I., de Matos, V., Porteiro, F.M., Ocana, O., 2011. Isozoanthus primnoidus, a new species of zoanthid (Cnidaria: Zoantharia) associated with the 
gorgonian Callogorgia verticillata (Cnidaria: Alcyonacea). Ices Journal of Marine Science 68, 408-415.10.1093/icesjms/fsq073

Cartes, J.E., Abello, P., Lloris, D., Carbonell, A., Torres, P., Maynou, F., De Sola, L.G., 2002. Feeding guilds of western Mediterranean demersal fish and crustaceans: an analysis based on a spring survey. Scientia Marina 66, 209-220

Cartes, J.E., Maynou, F., Lloris Samo, D., Gil Sola, L., García, M., 2009. Influence of trawl type on the composition and diversity of deep benthopelagic fish and decapod assemblages off the Catalan coasts (western Mediterranean). Scientia Marina 73, 725-737

Cartes, J.E., Maynou, F., Sardà, F., Company, J.B., Lloris Samo, D., Turdela, S., 2004. The Mediterranean deep-sea ecosystems Part I: An overview of their diversity, structure, functioning and anthropogenic impacts. 9-38.

Cau, A., Carbonell, A., Follesa, M.C., Mannini, A., Norrito, G., Orsi-Relini, L., Politou, C.Y., Ragonese, S., Rinelli, P., 2002. MEDITS-based information on the deep-water red shrimps Aristaeomorpha foliacea and Aristeus antennatus (Crustacea : Decapoda : Aristeidae). Scientia Marina 66, 103-124

Clarke, K.R., Warwick, R.M., 2001. Change in marine communities: an approach to statistical analysis and interpretation, 2nd edition.

Coll, M., Piroddi, C., Steenbeek, J., Kaschner, K., Ben Rais Lasram, F., Aguzzi, J., Ballesteros, E., Bianchi, C.N., Corbera, J., Dailianis, T., Danovaro, R., Estrada, M., Froglia, C., Galil, B.S., Gasol, J.M., Gertwagen, R., Gil, J., Guilhaumon, F., Kesner-Reyes, K., Kitsos, M.-S., Koukouras, A., Lampadariou, N., Laxamana, E., Lopez-Fe de la Cuadra, C.M., Lotze, H.K., Martin, D., Mouillot, D., Oro, D., Raicevich, S., Rius-Barile, J., Saiz-Salinas, J.I., San Vicente, C., Somot, S., Templado, J., Turon, X., Vafidis, D., Villanueva, R., Voultsiadou, E., 2010. The biodiversity of the Mediterranean Sea: estimates, patterns, and threats. Plos One 5, e11842

Company, J.B., Puig, P., Sarda, F., Palanques, A., Latasa, M., Scharek, R., 2008. Climate Influence on deep sea populations. Plos One 3, e1431.10.1371/journal.pone.0001431

Costantini, F., Taviani, M., Remia, A., Pintus, E., Schembri, P.J., Abbiati, M., 2010. Deep-water Corallium rubrum (L., 1758) from the Mediterranean Sea: preliminary genetic characterisation. Marine Ecology-an Evolutionary Perspective 31, 261-269.10.1111/j.14390485.2009.00333.x

Costello, M.J., Coll, M., Danovaro, R., Halpin, P., Ojaveer, H., Miloslavich, P., 2010. A census of marine biodiversity knowledge, resources, and future challenges. Plos One 5, e12110

D'Onghia, G., Politou, C.Y., Bozzano, A., Lloris, D., Rotllant, G., Sion, L., Mastrototaro, F., 2004. Deep-water fish assemblages in the Mediterranean Sea. Scientia Marina 68, 87-99

Danovaro, R., Company, J.B., Corinaldesi, C., D'Onghia, G., Galil, B.S., Gambi, C., Gooday, A., Lampadariou, N., Luna, G.M., Morigi, C., Olu, K., Polymenakou, P., Ramirez-Llodra, E., Sabbatini, A., Sarda, F., Sibuet, M., Tselepides, A., 2010. Deep-sea biodiversity in the Mediterranean Sea: The known, the unknown, and the knowable. Plos One 5, e11832

Dauvin, J.C., 2010. Towards an impact assessment of bauxite red mud waste on the knowledge of the structure and functions of bathyal ecosystems: The example of the Cassidaigne canyon (northwestern Mediterranean Sea). Marine Pollution Bulletin 60, 197206.10.1016/j.marpolbul.2009.09.026

De Mol, B., Amblas, D., Alvarez, G., Busquets, P., Calafat, A., Canals, M., Duran, R., Lavoie, C., Acosta, J., Munoz, A., 2012. Cold-water coral distribution in an erosional environment: the Strait of Gibraltar, in: Harris, P.T., Baker, E.K. (Eds.), Seafloor Geomorphology as Benthic Habitat. Elsevier, Amsterdam, pp. 635-643.

Demestre, M., Sanchez, P., Abello, P., 2000. Demersal fish assemblages and habitat characteristics on the continental shelf and upper slope of the north-western Mediterranean. Journal of the Marine Biological Association of the United Kingdom 80, 981988.10.1017/s0025315400003040

Dimech, M., Kaiser, M.J., Ragonese, S., Schembri, P.J., 2012. Ecosystem effects of fishing on the continental slope in the Central Mediterranean Sea. Marine Ecology-Progress Series 449, 4154.10.3354/meps09475 
Durrieu de Madron, X., Zervakis, V., Theocharis, A., Georgopoulos, D., 2005. Comments on "Cascades of dense water around the world ocean". Progress in Oceanography 64, 8390.10.1016/j.pocean.2004.08.004

European Commission, 2008. Regulation (EC 734/2008) on the protection of vulnerable marine ecosystems in he high seas from the adverse impacts of bottom fishing gears. Official Journal of the European Union

FAO, 2009. Report of the technical consultation on international guidelines for the management of dee-sea fisheries in the high seas. 881, FAO, 98.

Farrugio, H., 2012. A refugium for the spawners of exploited Mediterranean marine species: the canyons of the continental slope of the Gulf of Lion, in: Wurtz, M. (Ed.), Mediterranean Submarine Canyons : Ecology and Gorvernance. IUCN, Gland, Switzerland and Malaga, Spain, pp. 45-49.

Fink, H.G., Wienberg, C., De Pol-Holz, R., Wintersteller, P., Hebbeln, D., 2013. Cold-water coral growth in the Alboran Sea related to high productivity during the Late Pleistocene and Holocene. Marine Geology 339, 71-82

Fontanier, C., Fabri, M.C., Buscail, R., Biscara, L., Koho, K., Reichart, G.J., Cossa, D., Galaup, S., Chabaud, G., Pigot, L., 2012. Deep-sea foraminifera from the Cassidaigne Canyon (NW Mediterranean): Assessing the environmental impact of bauxite red mud disposal. Marine Pollution Bulletin 64, 1895-1910.10.1016/j.marpolbul.2012.06.016

Fredj, G., 1964. La région de Saint-Tropez: du cap Taillat au cap de Saint-Tropez (Région A1) Fascicule 2. Bull. Inst. océanogr. Monaco 63, 1-55

Freiwald, A., Beuck, L., Rüggeberg, A., Taviani, M., Hebbeln, D., 2009. The white coral community in the Central Mediterranean Sea revealed by ROV Surveys. Oceanography 22, 58-74

Galgani, F., Leaute, J.P., Moguedet, P., Souplet, A., Verin, Y., Carpentier, A., Goraguer, H., Latrouite, D., Andral, B., Cadiou, Y., Mahe, J.C., Poulard, J.C., Nerisson, P., 2000. Litter on the sea floor along European coasts. Marine Pollution Bulletin 40, 516-527

Galgani, F., Souplet, A., Cadiou, Y., 1996. Accumulation of debris on the deep sea floor off the French Mediterranean coast. Marine Ecology-Progress Series 142, 225-234

GFCM, S.A.C., 2009a. Criteria for the identification of sensitive habitats of relevance for the management of priority species (General Fisheries Commission for the Mediterranean). 3.

GFCM, S.A.C., 2009b. On the establishment of a Fisheries Restricted Area in the Gulf of Lions to protect spawning aggregations and deep sea sensitive habitats (GFCM/33/2009/1).

Gori, A., Orejas, C., Madurell, T., Bramanti, L., Martins, M., Quintanilla, E., Marti-Puig, P., Lo Iacono, C., Puig, P., Requena, S., Greenacre, M., Gili, J.M., 2013. Bathymetrical distribution and size structure of cold-water coral populations in the Cap de Creus and Lacaze-Duthiers canyons (northwestern Mediterranean). Biogeosciences 10, 2049-2060.10.5194/bg-10-20492013

Greene, H.G., Bizzarro, J.J., 2007. Construction of digital potential marine benthic habitat maps using a code classification scheme and its application, in: Todd, B.J., Greene, H.G. (Eds.), Mapping the Seafloor for Habitat Characterization: Geological Association of Canada, pp. 145-159.

Harris, P.T., Whiteway, T., 2011. Global distribution of large submarine canyons: Geomorphic differences between active and passive continental margins. Marine Geology 285, 6986.10.1016/j.margeo.2011.05.008

Huvenne, V.A.I., Tyler, P.A., Masson, D.G., Fisher, E.H., Hauton, C., Huehnerbach, V., Le Bas, T.P., Wolff, G.A., 2011. A Picture on the wall: Innovative mapping reveals cold-water coral refuge in submarine canyon. Plos One 6, e28755.e28755

10.1371/journal.pone.0028755

Keller, N.B., Os'kina, N.S., 2008. Habitat temperature ranges of azooxantellate scleractinian corals in the World Ocean. Oceanology 48, 77-84.10.1134/s0001437008010098

Lofi, J., Rabineau, M., Gorini, C., Berne, S., Clauzon, G., De Clarens, P., Dos Reis, A.T., Mountain, G.S., Ryan, W.B.F., Steckler, M.S., Fouchet, C., 2003. Plio-Quaternary prograding clinoform wedges of the western Gulf of Lion continental margin (NW Mediterranean) after the Messinian Salinity Crisis. Marine Geology 198, 289-317.10.1016/s0025-3227(03)00120-8

Loubrieu, B., Satra, C., 2010. Bathy-morphologie du plateau continental - Façades Méditerranéenne et Corse (édition 2010, 100 m). Ifremer, Plouzané, p. Modèle bathymétrique (MNT) à 100m de 
résolution de la façade maritime française de la Méditerranée. Le MNT a été réalisé par krigeage à partir d'une compilation des principales sources de données bathymétriques françaises.

MacDonald, D.S., Little, M., Eno, N.C., Hiscock, K., 1996. Disturbance of benthic species by fishing activities: A sensitivity index. Aquatic Conservation-Marine and Freshwater Ecosystems 6, 257-268.10.1002/(sici)1099-0755(199612)6:4<257::aid-aqc194>3.3.co;2-z

Martín, J., Puig, P., Palanques, A., Ribó, M., 2013. Trawling-induced daily sediment resuspension in the flank of a Mediterranean submarine canyon. Deep Sea Research II (this issue).http://dx.doi.org/10.1016/j.dsr2.2013.05.036

Maurin, C., 1962. Étude des fonds chalutables de la Méditerranée occidentale (Écologie et Pêche). Rev. Trav. Inst. Pêche marit. 26, 163-220

Maynou, F., Cartes, J.E., 2012. Effects of trawling on fish and invertebrates from deep-sea coral fades of Isidella elongata in the western Mediterranean. Journal of the Marine Biological Association of the United Kingdom 92, 1501-1507.10.1017/s0025315411001603

Maynou, F., Sarda, F., 1997. Nephrops norvegicus population and morphometrical characteristics in relation to substrate heterogeneity. Fisheries Research 30, 139-149.10.1016/s01657836(96)00549-8

Millot, C., 1990. The Gulf of Lions' hydrodynamics. Continental Shelf Research 10, 885-894

Mordecai, G., Tyler, P.A., Masson, D.G., Huvenne, V.A.I., 2011. Litter in submarine canyons off the west coast of Portugal. Deep-Sea Research II 58, 2489-2496.10.1016/j.dsr2.2011.08.009

Morfin, M., Fromentin, J.-M., Jadaud, A., Bez, N., 2012. Spatio-temporal patterns of key exploited marine species in the Northwestern Mediterranean Sea. Plos One 7, e37907.e37907

10.1371/journal.pone.0037907

Mytilineou, C., Sarda, F., 1995. Age and growth of Nephrops norvegicus in the Catalan Sea, using length-frequency analysis. Fisheries Research 23, 283-299.10.1016/0165-7836(94)00350-6

Orejas, C., Gori, A., Lo Iacono, C., Puig, P., Gili, J.M., Dale, M.R.T., 2009. Cold-water corals in the Cap de Creus canyon, northwestern Mediterranean: spatial distribution, density and anthropogenic impact. Marine Ecology-Progress Series 397, 37-51.10.3354/mep08314

Palanques, A., Durrieu de Madron, X., Puig, P., Fabres, J., Guillen, J., Calafat, A., Canals, M., Heussner, S., Bonnin, J., 2006. Suspended sediment fluxes and transport processes in the Gulf of Lions submarine canyons. The role of storms and dense water cascading. Marine Geology 234, 43-61.10.1016/j.margeo.2006.09.002

Peres, J.M., Picard, J., 1964. Nouveau Manuel de Bionomie benthique de la mer Méditerranée. Recueil des travaux de la Station Marine d'Endoûme 31, 1-137

Puig, P., Canals, M., Company, J.B., Martin, J., Amblas, D., Lastras, G., Palanques, A., Calafat, A.M., 2012. Ploughing the deep sea floor. Nature 489, 286-289.10.1038/nature11410

Puig, P., Palanques, A., Orange, D.L., Lastras, G., Canals, M., 2008. Dense shelf water cascades and sedimentary furrow formation in the Cap de Creus Canyon, northwestern Mediterranean Sea. Continental Shelf Research 28, 2017-2030.10.1016/j.csr.2008.05.002

Ramirez-Llodra, E., Tyler, P.A., Baker, M.C., Bergstad, O.A., Clark, M.R., Escobar, E., Levin, L.A., Menot, L., Rowden, A.A., Smith, C.R., Van Dover, C.L., 2011. Man and the last great wilderness: human impact on the deep sea. Plos One 6, e22588

Ramsay, K., Kaiser, M.J., Hughes, R.N., 1998. Responses of benthic scavengers to fishing disturbance by towed gears in different habitats. Journal of Experimental Marine Biology and Ecology 224, 73-89.10.1016/s0022-0981(97)00170-6

Relini-Orsi, L., Relini, G., 1972. Note sui Crostacei Decapodi batiali del Mar Ligure. Boll. Mus. Ist Biol. Univ. Genova 40, 47-73

Reyss, D., 1970. Bionomie benthique de deux canyons sous-marins de la mer Catalane: le Rech du Cap et le Rech Lacaze-Duthiers, Paris. Université de Paris VI, p. 255.

Risk, M.J., Heikoop, J.M., Snow, M.G., Beukens, R., 2002. Lifespans and growth patterns of two deep-sea corals: Primnoa resedaeformis and Desmophyllum cristagalli. Hydrobiologia 471, $125-131$

Sacchi, J., 2008. The use of trawling nets in the Mediterranean. Problems and selectivity options. Options Mediterranéennes Series B, 87-96 
Sampaio, Í., Braga-Henriques, A., Pham, C., Ocaña, O., de Matos, V., Morato, T., Porteiro, F.M., 2012. Cold-water corals landed by bottom longline fisheries in the Azores (north-eastern Atlantic). Journal of the Marine Biological Association of the United Kingdom 92, 15471555.doi:10.1017/S0025315412000045

Sanchez, F., Serrano, A., Ballesteros, M.G., 2009. Photogrammetric quantitative study of habitat and benthic communities of deep Cantabrian Sea hard grounds. Continental Shelf Research 29, 1174-1188.10.1016/j.csr.2009.01.004

Sanchez, P., Maynou, F., Demestre, M., 2004. Modelling catch, effort and price in a juvenile Eledone cirrhosa fishery over a 10-year period. Fisheries Research 68, 319327.10.1016/j.fishres.2003.11.008

Sarda, F., 1998. Nephrops norvegicus (L): Comparative biology and fishery in the Mediterranean Sea. Introduction, conclusions and recommendations. Scientia Marina 62, 5-15

Sarda, F., D'Onghia, G., Politou, C.Y., Company, J.B., Maiorano, P., Kapiris, K., 2004. Deep-sea distribution, biological and ecological aspects of Aristeus antennatus (Risso, 1816) in the western and central Mediterranean Sea. Scientia Marina 68, 117-127

Sherwood, O.A., Thresher, R.E., Fallon, S.J., Davies, D.M., Trull, T.W., 2009. Multi-century timeseries of ${ }^{15} \mathrm{~N}$ and ${ }^{14} \mathrm{C}$ in bamboo corals from deep Tasmanian seamounts: evidence for stable oceanographic conditions. Mar. Ecol. Prog. Ser. 397, 209-218

Spengler, A., Costa, M.F., 2008. Methods applied in studies of benthic marine debris. Marine Pollution Bulletin 56, 226-230.10.1016/j.marpolbul.2007.09.040

Tully, O., Hillis, J.P., 1995. Causes and spatial scales of variability in population-structure of Nephrops norvegicus (L.) in the Irish Sea. Fisheries Research 21, 329-347.10.1016/01657836(94)00303-e

United Nation, 2007. Resolution 61/105 adopted by the General Assembly on Sustainable fisheries, including through the 1995 Agreement for the Implementation of the Provisions of the United Nations Convention on the Law of the Sea of 10 December 1982 relating to the Conservation and Management of Straddling Fish Stocks and Highly Migratory Fish Stocks, and related instruments. Resolution 61/105 adopted by the General Assembly 61/105, ONU, 23.

Wagner, D., Luck, D.G., Toonen, R.J., 2012. The biology and ecology of black corals (Cnidaria: Anthozoa: Hexacorallia: Antipatharia). Adv Mar Biol 63, 67-132.B978-0-12-394282-1.000028 [pii]

10.1016/B978-0-12-394282-1.00002-8 [doi]

Watremez, P., 2012. Canyon heads in the French Mediterranean Sea - Overview of results from the MEDSEACAN and CORSEACAN campaigns (2008-2010), in: Wurtz, M. (Ed.), Mediterranean Submarine Canyons: Ecology and Governance. IUCN, Gland, Switzerland, pp. 105-112.

Williams, B., Risk, M., Stone, R., Sinclair, D., Ghaleb, B., 2007. Oceanographic changes in the North Pacific Ocean over the past century recorded in deep-water gorgonian corals. Marine EcologyProgress Series 335, 85-94.10.3354/meps335085

Zibrowius, H., 1980. Les Scléractiniaires de la Méditerranée et de l'Atlantique nord-oriental. Mémoires de l'Institut Océanographique de Monaco 11, 1-238

Zibrowius, H., 2003. La communauté des "coraux blancs", les faunes des canyons et des montagnes sous-marines de la Mediterranée profonde. Plan d'Action Stratégique pour la Conservation de la Biodiversité dans la Région Méditerranéenne (PAS BIO), 43. 
1399

1400

1401

1402

1403

1404

Table 1

List of MEDSEACAN 2009 dives ordered by canyon. For each dive the latitude/longitude of the dive's gravity centre, the length of the navigation track, the depth ( $\mathrm{min}, \mathrm{max}$, mean), the distance to the coast, the mean slope and the percentage of hard/soft substrate are mentioned. Canyons are listed from westward to eastward.

\begin{tabular}{|c|c|c|c|c|c|c|c|c|c|c|c|c|}
\hline Canyon & \begin{tabular}{|c|} 
Explored \\
length \\
$(\mathrm{km})$
\end{tabular} & $\begin{array}{c}\text { Dive } \\
\mathrm{nb}\end{array}$ & Latitude & Longitude & $\begin{array}{l}\text { Length } \\
\text { (m) }\end{array}$ & $\begin{array}{c}\text { Min } \\
\operatorname{Depth}(\mathrm{m})\end{array}$ & $\begin{array}{c}\text { Max } \\
\text { Depth }(\mathrm{m})\end{array}$ & $\begin{array}{c}\text { Mean } \\
\text { Depth }(\mathrm{m})\end{array}$ & $\begin{array}{l}\text { Distance } \\
\text { (degrees) }\end{array}$ & $\begin{array}{c}\text { Mean } \\
\text { slope } \\
\text { (degree) }\end{array}$ & $\begin{array}{c}\text { Hard } \\
\text { substrate } \\
(\%) \\
\end{array}$ & $\begin{array}{c}\text { Soft } \\
\text { substrate } \\
(\%)\end{array}$ \\
\hline \multirow{8}{*}{ Lacaze-Duthiers } & \multirow{8}{*}{10.97} & $\mathrm{P} 2$ & $42^{\circ} 33.294 \mathrm{~N}$ & $3^{\circ} 24.090 \mathrm{E}$ & 606 & 240 & 256 & 248 & 0.2445 & 27 & 100 & 0 \\
\hline & & P3 & $42^{\circ} 35.010 \mathrm{~N}$ & $3^{\circ} 24.258 \mathrm{E}$ & 1553 & 200 & 310 & 255 & 0.2669 & 19 & 50 & 50 \\
\hline & & P6 & $42^{\circ} 32.598 \mathrm{~N}$ & $3^{\circ} 25.056 \mathrm{E}$ & 1752 & 200 & 542 & 371 & 0.2398 & 24 & 20 & 80 \\
\hline & & P7 & $42^{\circ} 32.934 \mathrm{~N}$ & $3^{\circ} 26.316 \mathrm{E}$ & 1490 & 183 & 550 & 367 & 0.2541 & 26 & 0 & 100 \\
\hline & & $\mathrm{P} 11$ & $42^{\circ} 35.028 \mathrm{~N}$ & $3^{\circ} 23.280 \mathrm{E}$ & 990 & 183 & 280 & 232 & 0.2535 & 19 & 50 & 50 \\
\hline & & $\mathrm{P} 13$ & $42^{\circ} 31.152 \mathrm{~N}$ & $3^{\circ} 26.388 \mathrm{E}$ & 2853 & 201 & 665 & 433 & 0.2292 & 22 & 0 & 100 \\
\hline & & P14 & $42^{\circ} 34.794 \mathrm{~N}$ & $3^{\circ} 24.336 \mathrm{E}$ & 595 & 203 & 360 & 282 & 0.2665 & 19 & 50 & 50 \\
\hline & & P15 & $42^{\circ} 33.816 \mathrm{~N}$ & $3^{\circ} 23.862 \mathrm{E}$ & 1131 & 321 & 385 & 226 & 0.2516 & 33 & 80 & 20 \\
\hline \multirow{4}{*}{ Pruvost } & \multirow{4}{*}{3.84} & P1 & $42^{\circ} 30.618 \mathrm{~N}$ & $3^{\circ} 32.646 \mathrm{E}$ & 1489 & 202 & 523 & 363 & 0.2924 & 20 & 0 & 100 \\
\hline & & $\mathrm{P} 2$ & $42^{\circ} 31.980 \mathrm{~N}$ & $3^{\circ} 32.928 \mathrm{E}$ & 1035 & 200 & 475 & 338 & 0.3100 & 21 & 0 & 100 \\
\hline & & P5 & $42^{\circ} 32.454 \mathrm{~N}$ & $3^{\circ} 30.444 \mathrm{E}$ & 316 & 180 & 235 & 208 & 0.2877 & 14 & 0 & 100 \\
\hline & & P6 & $42^{\circ} 33.360 \mathrm{~N}$ & $3^{\circ} 31.560 \mathrm{E}$ & 996 & 194 & 368 & 281 & 0.3116 & 17 & 0 & 100 \\
\hline \multirow{4}{*}{ Bourcart } & \multirow{4}{*}{6.16} & $\mathrm{P} 2$ & $42^{\circ} 43.248 \mathrm{~N}$ & $3^{\circ} 40.860 \mathrm{E}$ & 1359 & 203 & 463 & 333 & 0.5379 & 19 & 0 & 100 \\
\hline & & $\mathrm{P} 5$ & $42^{\circ} 36.792 \mathrm{~N}$ & $3^{\circ} 45.114 \mathrm{E}$ & 1584 & 377 & 625 & 501 & 0.5203 & 24 & 0 & 100 \\
\hline & & P6 & $42^{\circ} 43.476 \mathrm{~N}$ & $3^{\circ} 44.778 \mathrm{E}$ & 1669 & 253 & 403 & 328 & 0.5857 & 12 & 0 & 100 \\
\hline & & BO_R2K & $42^{\circ} 44.670 \mathrm{~N}$ & $3^{\circ} 43.050 \mathrm{E}$ & 1549 & 310 & 360 & 335 & 0.5605 & 15 & 90 & 100 \\
\hline \multirow{4}{*}{ Marti } & \multirow{4}{*}{5.38} & $\mathrm{P} 1$ & $42^{\circ} 43.326 \mathrm{~N}$ & $3^{\circ} 57.660 \mathrm{E}$ & 1988 & 374 & 609 & 492 & 0.7081 & 24 & 0 & 100 \\
\hline & & $\mathrm{P} 2$ & $42^{\circ} 47.538 \mathrm{~N}$ & $3^{\circ} 55.980 \mathrm{E}$ & 1348 & 190 & 378 & 284 & 0.6357 & 15 & 0 & 100 \\
\hline & & P4 & $42^{\circ} 47.184 \mathrm{~N}$ & $3^{\circ} 57.816 \mathrm{E}$ & 672 & 226 & 347 & 287 & 0.6611 & 22 & 0 & 100 \\
\hline & & P5 & $42^{\circ} 43.926 \mathrm{~N}$ & $4^{\circ} 0.282 \mathrm{E}$ & 1367 & 329 & 605 & 467 & 0.7264 & 21 & 0 & 100 \\
\hline \multirow{4}{*}{ Sète } & \multirow{4}{*}{4.73} & $\mathrm{P} 1$ & $42^{\circ} 41.976 \mathrm{~N}$ & $4^{\circ} 9.606 \mathrm{E}$ & 1320 & 279 & 626 & 453 & 0.7610 & 20 & 0 & 100 \\
\hline & & $\mathrm{P} 2$ & $42^{\circ} 45.696 \mathrm{~N}$ & $4^{\circ} 7.932 \mathrm{E}$ & 1214 & 315 & 540 & 428 & 0.7026 & 23 & 0 & 100 \\
\hline & & P3 & $42^{\circ} 44.718 \mathrm{~N}$ & $4^{\circ} 11.298 \mathrm{E}$ & 1856 & 231 & 700 & 466 & 0.7151 & 21 & 0 & 100 \\
\hline & & P8 & $42^{\circ} 47.892 \mathrm{~N}$ & $4^{\circ} 6.534 \mathrm{E}$ & 338 & 180 & 235 & 208 & 0.6701 & 4 & 0 & 100 \\
\hline \multirow{4}{*}{ Montpellier } & \multirow{4}{*}{8.96} & $\mathrm{P} 1$ & $42^{\circ} 48.906 \mathrm{~N}$ & $4^{\circ} 22.548 \mathrm{E}$ & 3495 & 200 & 700 & 450 & 0.5817 & 20 & 0 & 100 \\
\hline & & $\mathrm{P} 2$ & $42^{\circ} 47.640 \mathrm{~N}$ & $4^{\circ} 24.504 \mathrm{E}$ & 1550 & 185 & 613 & 399 & 0.5901 & 26 & 0 & 100 \\
\hline & & P3 & $42^{\circ} 45.456 \mathrm{~N}$ & $4^{\circ} 23.472 \mathrm{E}$ & 2038 & 260 & 600 & 430 & 0.6293 & 22 & 0 & 100 \\
\hline & & P4 & $42^{\circ} 49.134 \mathrm{~N}$ & $4^{\circ} 26.874 \mathrm{E}$ & 1881 & 200 & 402 & 301 & 0.5555 & 10 & 0 & 100 \\
\hline \multirow{4}{*}{ Petit-Rhône } & \multirow{4}{*}{9.24} & $\mathrm{P} 1$ & $42^{\circ} 58.038 \mathrm{~N}$ & $4^{\circ} 29.010 \mathrm{E}$ & 1899 & 343 & 408 & 376 & 0.4033 & 4 & 0 & 100 \\
\hline & & P3 & $42^{\circ} 55.212 \mathrm{~N}$ & $4^{\circ} 30.780 \mathrm{E}$ & 2367 & 180 & 487 & 334 & 0.4413 & 27 & 0 & 100 \\
\hline & & P4 & $42^{\circ} 51.882 \mathrm{~N}$ & $4^{\circ} 39.930 \mathrm{E}$ & 1891 & 268 & 600 & 434 & 0.4800 & 16 & 0 & 100 \\
\hline & & P5 & $42^{\circ} 50.316 \mathrm{~N}$ & $4^{\circ} 29.340 \mathrm{E}$ & 3084 & 206 & 627 & 417 & 0.5265 & 14 & 0 & 100 \\
\hline \multirow{3}{*}{ Grand-Rhône } & \multirow{3}{*}{5.83} & $\mathrm{P} 1$ & $42^{\circ} 54.738 \mathrm{~N}$ & $4^{\circ} 45.336 \mathrm{E}$ & 1794 & 180 & 420 & 300 & 0.4232 & 13 & 0 & 100 \\
\hline & & $\mathrm{P} 2$ & $42^{\circ} 55.116 \mathrm{~N}$ & $4^{\circ} 50.232 \mathrm{E}$ & 1669 & 190 & 427 & 309 & 0.4100 & 17 & 0 & 100 \\
\hline & & P3 & $42^{\circ} 58.134 \mathrm{~N}$ & $4^{\circ} 47.778 \mathrm{E}$ & 2366 & 410 & 443 & 427 & 0.3620 & 15 & 0 & 100 \\
\hline \multirow{6}{*}{ Couronne } & \multirow{6}{*}{10.40} & $\mathrm{P} 1$ & $43^{\circ} 2.250 \mathrm{~N}$ & $5^{\circ} 1.518 \mathrm{E}$ & 1804 & 202 & 571 & 387 & 0.2870 & 17 & 0 & 100 \\
\hline & & $\mathrm{P} 2$ & $43^{\circ} 3.330 \mathrm{~N}$ & $5^{\circ} 6.918 \mathrm{E}$ & 1896 & 200 & 500 & 350 & 0.2600 & 14 & 0 & 100 \\
\hline & & P3 & $43^{\circ} 3.960 \mathrm{~N}$ & $5^{\circ} 8.256 \mathrm{E}$ & 1299 & 203 & 501 & 352 & 0.2365 & 18 & 0 & 100 \\
\hline & & $\mathrm{P} 4$ & $43^{\circ} 0.354 \mathrm{~N}$ & $5^{\circ} 1.242 \mathrm{E}$ & 1962 & 209 & 551 & 380 & 0.3194 & 18 & 0 & 100 \\
\hline & & P5 & $43^{\circ} 1.890 \mathrm{~N}$ & $5^{\circ} 4.302 \mathrm{E}$ & 2118 & 275 & 550 & 413 & 0.2924 & 13 & 0 & 100 \\
\hline & & P6 & $43^{\circ} 0.618 \mathrm{~N}$ & $5^{\circ} 7.848 \mathrm{E}$ & 1324 & 325 & 542 & 434 & 0.2800 & 18 & 0 & 100 \\
\hline Planier & 17.90 & P1 & $43^{\circ} 6.108 \mathrm{~N}$ & $5^{\circ} 12.372 \mathrm{E}$ & 1033 & 213 & 420 & 317 & 0.1613 & 20 & 60 & 40 \\
\hline
\end{tabular}




\begin{tabular}{|c|c|c|c|c|c|c|c|c|c|c|c|c|}
\hline & & P2 & $43^{\circ} 5.316 \mathrm{~N}$ & $5^{\circ} 12.540 \mathrm{E}$ & 728 & 338 & 554 & 446 & 0.1683 & 32 & 90 & 10 \\
\hline & & P3 & $43^{\circ} 4.386 \mathrm{~N}$ & 5॰13.194 E & 983 & 309 & 640 & 475 & 0.1737 & 29 & 50 & 50 \\
\hline & & P4 & $43^{\circ} 3.882 \mathrm{~N}$ & $5^{\circ} 8.400 \mathrm{E}$ & 2553 & 180 & 585 & 383 & 0.2361 & 19 & 0 & 100 \\
\hline & & P5 & $43^{\circ} 5.982 \mathrm{~N}$ & $5^{\circ} 13.938 \mathrm{E}$ & 528 & 418 & 486 & 452 & 0.1445 & 11 & 0 & 100 \\
\hline & & P6 & $43^{\circ} 7.188 \mathrm{~N}$ & $5^{\circ} 12.684 \mathrm{E}$ & 1517 & 180 & 313 & 247 & 0.1449 & 13 & 10 & 90 \\
\hline & & P7 & $43^{\circ} 6.432 \mathrm{~N}$ & $5^{\circ} 12.456 \mathrm{E}$ & 3954 & 200 & 452 & 326 & 0.1571 & 18 & 70 & 20 \\
\hline & & P8 & $43^{\circ} 6.552 \mathrm{~N}$ & $5^{\circ} 14.526 \mathrm{E}$ & 675 & 340 & 390 & 365 & 0.1319 & 11 & 60 & 40 \\
\hline & & P9 & $43^{\circ} 4.944 \mathrm{~N}$ & $5^{\circ} 11.670 \mathrm{E}$ & 1884 & 200 & 593 & 397 & 0.1838 & 21 & 10 & 90 \\
\hline & & $\mathrm{P} 10$ & $43^{\circ} 5.376 \mathrm{~N}$ & $5^{\circ} 14.082 \mathrm{E}$ & 1868 & 232 & 425 & 329 & 0.1509 & 12 & 0 & 100 \\
\hline & & P11 & $43^{\circ} 6.732 \mathrm{~N}$ & $5^{\circ} 14.514 \mathrm{E}$ & 859 & 195 & 340 & 268 & 0.1289 & 14 & 50 & 50 \\
\hline & & P12 & $43^{\circ} 5.718 \mathrm{~N}$ & $5^{\circ} 12.642 \mathrm{E}$ & 498 & 225 & 439 & 332 & 0.1641 & 34 & 90 & 10 \\
\hline & & $\mathrm{P} 13$ & $43^{\circ} 5.496 \mathrm{~N}$ & $5^{\circ} 12.564 \mathrm{E}$ & 824 & 266 & 413 & 340 & 0.1655 & 34 & 90 & 10 \\
\hline \multirow{7}{*}{ Cassidaigne } & \multirow{7}{*}{8.12} & $\mathrm{P} 1$ & $43^{\circ} 6.756 \mathrm{~N}$ & $5^{\circ} 27.630 \mathrm{E}$ & 2179 & 205 & 215 & 210 & 0.0863 & 19 & 100 & 0 \\
\hline & & P2 & $43^{\circ} 2.598 \mathrm{~N}$ & $5^{\circ} 24.048 \mathrm{E}$ & 1327 & 448 & 634 & 541 & 0.1282 & 41 & 100 & 0 \\
\hline & & P3 & $43^{\circ} 2.808 \mathrm{~N}$ & $5^{\circ} 23.850 \mathrm{E}$ & 1210 & 285 & 470 & 378 & 0.1241 & 27 & 80 & 20 \\
\hline & & P4 & $43^{\circ} 5.364 \mathrm{~N}$ & $5^{\circ} 25.752 \mathrm{E}$ & 767 & 180 & 386 & 283 & 0.0899 & 29 & 70 & 30 \\
\hline & & P6 & $43^{\circ} 8.028 \mathrm{~N}$ & $5^{\circ} 28.158 \mathrm{E}$ & 855 & 210 & 465 & 338 & 0.0672 & 22 & 20 & 80 \\
\hline & & P7 & $43^{\circ} 1.272 \mathrm{~N}$ & $5^{\circ} 29.184 \mathrm{E}$ & 900 & 200 & 470 & 335 & 0.1729 & 36 & 60 & 40 \\
\hline & & P8 & $43^{\circ} 3.636 \mathrm{~N}$ & $5^{\circ} 29.400 \mathrm{E}$ & 879 & 214 & 508 & 361 & 0.1361 & 33 & 60 & 40 \\
\hline \multirow{4}{*}{ La Ciotat } & \multirow{4}{*}{7.25} & $\mathrm{P} 1$ & $43^{\circ} 1.404 \mathrm{~N}$ & $5^{\circ} 43.254 \mathrm{E}$ & 2091 & 180 & 600 & 390 & 0.0738 & 30 & 80 & 20 \\
\hline & & P2 & $43^{\circ} 0.498 \mathrm{~N}$ & $5^{\circ} 40.848 \mathrm{E}$ & 1350 & 180 & 498 & 339 & 0.1122 & 20 & 80 & 20 \\
\hline & & P3 & $42^{\circ} 58.746 \mathrm{~N}$ & $5^{\circ} 42.024 \mathrm{E}$ & 2492 & 216 & 583 & 400 & 0.1206 & 19 & 20 & 80 \\
\hline & & P5 & $42^{\circ} 57.780 \mathrm{~N}$ & $5^{\circ} 38.028 \mathrm{E}$ & 1318 & 180 & 518 & 349 & 0.1771 & 24 & 40 & 60 \\
\hline \multirow{6}{*}{ Sicié } & \multirow{6}{*}{8.70} & $\mathrm{P} 1$ & $43^{\circ} 0.846 \mathrm{~N}$ & $5^{\circ} 52.542 \mathrm{E}$ & 1449 & 180 & 398 & 289 & 0.0358 & 22 & 40 & 60 \\
\hline & & $\mathrm{P} 2$ & $42^{\circ} 59.538 \mathrm{~N}$ & $5^{\circ} 54.630 \mathrm{E}$ & 1446 & 180 & 486 & 333 & 0.0736 & 32 & 30 & 70 \\
\hline & & P4 & $43^{\circ} 0.972 \mathrm{~N}$ & $5^{\circ} 53.604 \mathrm{E}$ & 1516 & 180 & 580 & 380 & 0.0453 & 32 & 40 & 60 \\
\hline & & P5 & $42^{\circ} 59.958 \mathrm{~N}$ & $5^{\circ} 51.612 \mathrm{E}$ & 2460 & 180 & 560 & 370 & 0.0480 & 27 & 10 & 90 \\
\hline & & $\mathrm{P} 7$ & $43^{\circ} 0.936 \mathrm{~N}$ & $5^{\circ} 52.434 \mathrm{E}$ & 529 & 180 & 280 & 230 & 0.0331 & 20 & 50 & 50 \\
\hline & & P8 & $43^{\circ} 0.660 \mathrm{~N}$ & $5^{\circ} 55.038 \mathrm{E}$ & 1296 & 185 & 420 & 303 & 0.0560 & 31 & 70 & 30 \\
\hline \multirow{4}{*}{ Toulon } & \multirow{4}{*}{7.75} & P4 & $43^{\circ} 24.048 \mathrm{~N}$ & $6^{\circ} 55.212 \mathrm{E}$ & 2021 & 180 & 731 & 456 & 0.0382 & 24 & 30 & 70 \\
\hline & & P5 & $43^{\circ} 2.346 \mathrm{~N}$ & $5^{\circ} 58.158 \mathrm{E}$ & 1502 & 180 & 547 & 364 & 0.0369 & 20 & 40 & 60 \\
\hline & & P6 & $42^{\circ} 58.416 \mathrm{~N}$ & $5^{\circ} 57.000 \mathrm{E}$ & 2033 & 190 & 687 & 439 & 0.0921 & 22 & 90 & 10 \\
\hline & & $\mathrm{P} 7$ & $43^{\circ} 1.932 \mathrm{~N}$ & $6^{\circ} 0.198 \mathrm{E}$ & 2192 & 180 & 593 & 387 & 0.0487 & 25 & 40 & 60 \\
\hline \multirow{10}{*}{ Open slope } & \multirow{10}{*}{17.69} & PO_P1 & $42^{\circ} 56.838 \mathrm{~N}$ & $6^{\circ} 16.866 \mathrm{E}$ & 651 & 402 & 645 & 524 & 0.0611 & 30 & 90 & 10 \\
\hline & & PO_P5 & $42^{\circ} 57.624 \mathrm{~N}$ & $6^{\circ} 19.938 \mathrm{E}$ & 1332 & 180 & 627 & 404 & 0.0533 & 40 & 40 & 60 \\
\hline & & PO_P6 & $42^{\circ} 56.400 \mathrm{~N}$ & $6^{\circ} 14.076 \mathrm{E}$ & 2285 & 202 & 418 & 310 & 0.0494 & 27 & 30 & 70 \\
\hline & & PO_P8 & $42^{\circ} 56.646 \mathrm{~N}$ & $6^{\circ} 6.426 \mathrm{E}$ & 3230 & 195 & 710 & 453 & 0.0764 & 28 & 20 & 80 \\
\hline & & PO_P9 & $42^{\circ} 56.862 \mathrm{~N}$ & $6^{\circ} 14.982 \mathrm{E}$ & 2244 & 200 & 705 & 453 & 0.0481 & 29 & 60 & 40 \\
\hline & & PO_P10 & $42^{\circ} 56.280 \mathrm{~N}$ & $6^{\circ} 7.914 \mathrm{E}$ & 1748 & 317 & 557 & 437 & 0.0671 & 17 & 30 & 70 \\
\hline & & MG_P10 & $43^{\circ} 1.488 \mathrm{~N}$ & $6^{\circ} 38.742 \mathrm{E}$ & 1332 & 250 & 598 & 424 & 0.1358 & 32 & 20 & 80 \\
\hline & & MG_P11 & $42^{\circ} 57.840 \mathrm{~N}$ & $6^{\circ} 21.234 \mathrm{E}$ & 1516 & 180 & 800 & 490 & 0.0367 & 36 & 60 & 40 \\
\hline & & MG_P16 & $43^{\circ} 0.060 \mathrm{~N}$ & $6^{\circ} 32.088 \mathrm{E}$ & 1804 & 224 & 548 & 386 & 0.0501 & 32 & 70 & 30 \\
\hline & & MG_P17 & $43^{\circ} 0.210 \mathrm{~N}$ & $6^{\circ} 29.766 \mathrm{E}$ & 1544 & 180 & 673 & 427 & 0.0268 & 35 & 70 & 30 \\
\hline \multirow{7}{*}{ Stoechades } & \multirow{7}{*}{7.39} & MG_P3 & $43^{\circ} 4.362 \mathrm{~N}$ & $6^{\circ} 31.674 \mathrm{E}$ & 1515 & 252 & 707 & 480 & 0.0283 & 32 & 40 & 60 \\
\hline & & MG_P4 & $43^{\circ} 3.846 \mathrm{~N}$ & $6^{\circ} 28.266 \mathrm{E}$ & 695 & 180 & 394 & 287 & 0.0161 & 20 & 0 & 100 \\
\hline & & MG_P5 & $43^{\circ} 8.730 \mathrm{~N}$ & $6^{\circ} 40.686 \mathrm{E}$ & 1283 & 180 & 722 & 451 & 0.0361 & 30 & 40 & 60 \\
\hline & & MG_P6 & $43^{\circ} 8.058 \mathrm{~N}$ & $6^{\circ} 33.738 \mathrm{E}$ & 1200 & 200 & 515 & 358 & 0.0397 & 21 & 0 & 100 \\
\hline & & MG_P7 & $43^{\circ} 5.244 \mathrm{~N}$ & $6^{\circ} 26.916 \mathrm{E}$ & 558 & 300 & 322 & 311 & 0.0465 & 6 & 0 & 100 \\
\hline & & MG_P14 & $43^{\circ} 4.470 \mathrm{~N}$ & $6^{\circ} 34.296 \mathrm{E}$ & 956 & 302 & 652 & 477 & 0.0662 & 34 & 10 & 90 \\
\hline & & MG_P15 & $43^{\circ} 8.868 \mathrm{~N}$ & $6^{\circ} 37.368 \mathrm{E}$ & 1180 & 200 & 524 & 362 & 0.0100 & 32 & 70 & 30 \\
\hline
\end{tabular}


1405

1406

1407

1408

1409

1410

1411

1412

1413

1414

1415

1416

\begin{tabular}{|c|c|c|c|c|c|c|c|c|c|c|c|c|}
\hline \multirow{4}{*}{ Cannes } & \multirow{4}{*}{11.15} & P3 & $43^{\circ} 29.754 \mathrm{~N}$ & $7^{\circ} 1.236 \mathrm{E}$ & 2905 & 180 & 692 & 436 & 0.0189 & 29 & 10 & 30 \\
\hline & & P4 & $43^{\circ} 29.784 \mathrm{~N}$ & $6^{\circ} 58.824 \mathrm{E}$ & 2440 & 180 & 537 & 359 & 0.0240 & 32 & 50 & 50 \\
\hline & & P5 & $43^{\circ} 30.744 \mathrm{~N}$ & $6^{\circ} 58.716 \mathrm{E}$ & 1680 & 200 & 484 & 342 & 0.0242 & 23 & 0 & 100 \\
\hline & & P6 & $43^{\circ} 28.794 \mathrm{~N}$ & $7^{\circ} 3.516 \mathrm{E}$ & 4128 & 180 & 631 & 406 & 0.0260 & 32 & 0 & 100 \\
\hline \multirow{5}{*}{ Var } & \multirow{5}{*}{15.47} & P1 & $43^{\circ} 40.656 \mathrm{~N}$ & $7^{\circ} 17.238 \mathrm{E}$ & 6332 & 180 & 700 & 440 & 0.0100 & 26 & 20 & 80 \\
\hline & & P2 & $43^{\circ} 39.930 \mathrm{~N}$ & $7^{\circ} 20.790 \mathrm{E}$ & 2279 & 180 & 355 & 268 & 0.0144 & 17 & 10 & 90 \\
\hline & & P6 & $43^{\circ} 40.932 \mathrm{~N}$ & $7^{\circ} 17.610 \mathrm{E}$ & 324 & 180 & 290 & 235 & 0.0028 & 38 & 100 & 0 \\
\hline & & P10 & $43^{\circ} 35.748 \mathrm{~N}$ & $7^{\circ} 10.434 \mathrm{E}$ & 2455 & 315 & 586 & 451 & 0.0428 & 24 & 40 & 60 \\
\hline & & P11 & $43^{\circ} 35.898 \mathrm{~N}$ & $7^{\circ} 9.918 \mathrm{E}$ & 4082 & 180 & 456 & 318 & 0.0354 & 29 & 20 & 80 \\
\hline
\end{tabular}

Table 2

List of additional dives processed for qualitative information in the Lacaze-Duthiers and Cassidaigne canyons. For each dive the length of the navigation track, the latitude of the dive's gravity centre, the longitude of the dive's gravity centre and the depth (min, max, mean) are mentioned.

\begin{tabular}{|c|c|c|c|c|c|c|c|c|}
\hline Canyon & Cruise & $\begin{array}{c}\text { Dive } \\
\mathrm{nb}\end{array}$ & Latitude & Longitude & $\begin{array}{l}\text { Length } \\
\text { (m) }\end{array}$ & $\begin{array}{c}\operatorname{Min} \\
\operatorname{Depth}(\mathrm{m})\end{array}$ & $\begin{array}{c}\text { Max } \\
\text { Depth (m) }\end{array}$ & $\begin{array}{c}\text { Mean } \\
\text { Depth }(\mathrm{m})\end{array}$ \\
\hline \multirow{6}{*}{ Lacaze-Duthiers } & \multirow{6}{*}{$\begin{array}{c}\text { Marum } \\
\text { Senckenberg } \\
2011 \\
\text { Super Achille } \\
\text { ROV }\end{array}$} & D1 & $42^{\circ} 33.553 \mathrm{~N}$ & $3^{\circ} 25.540 \mathrm{E}$ & 847 & 250 & 450 & 350 \\
\hline & & $\mathrm{D} 2$ & $42^{\circ} 33.677 \mathrm{~N}$ & $3^{\circ} 23.945 \mathrm{E}$ & 35 & 300 & 350 & 325 \\
\hline & & D3 & $42^{\circ} 33.675 \mathrm{~N}$ & $3^{\circ} 23.953 \mathrm{E}$ & 1905 & 325 & 325 & 325 \\
\hline & & D5 & $42^{\circ} 28.300 \mathrm{~N}$ & $3^{\circ} 27.300 \mathrm{E}$ & 1905 & 200 & 600 & 400 \\
\hline & & D6 & $42^{\circ} 33.100 \mathrm{~N}$ & $3^{\circ} 24.460 \mathrm{E}$ & 494 & 250 & 450 & 350 \\
\hline & & D7 & $42^{\circ} 33.110 \mathrm{~N}$ & $3^{\circ} 24.451 \mathrm{E}$ & 249 & 250 & 400 & 375 \\
\hline \multirow{17}{*}{ Cassidaigne } & \multirow{9}{*}{$\begin{array}{l}\text { Marum } \\
2009 \\
\text { Super Achille } \\
\text { ROV }\end{array}$} & D1 & $43^{\circ} 7.094 \mathrm{~N}$ & $5^{\circ} 28.404 \mathrm{E}$ & 97 & 460 & 478 & 469 \\
\hline & & $\mathrm{D} 2$ & $43^{\circ} 6.507 \mathrm{~N}$ & $5^{\circ} 27.249 \mathrm{E}$ & 2745 & 184 & 240 & 212 \\
\hline & & D3 & $43^{\circ} 3.170 \mathrm{~N}$ & $5^{\circ} 28.602 \mathrm{E}$ & 963 & 516 & 564 & 540 \\
\hline & & D4 & $43^{\circ} 3.280 \mathrm{~N}$ & $5^{\circ} 29.905 \mathrm{E}$ & 1670 & 231 & 419 & 325 \\
\hline & & D5 & $43^{\circ} 6.603 \mathrm{~N}$ & $5^{\circ} 26.756 \mathrm{E}$ & 1561 & 198 & 370 & 284 \\
\hline & & D6 & $43^{\circ} 6.810 \mathrm{~N}$ & $5^{\circ} 25.930 \mathrm{E}$ & 1070 & 134 & 280 & 207 \\
\hline & & D7 & $43^{\circ} 6.712 \mathrm{~N}$ & $5^{\circ} 27.153 \mathrm{E}$ & 2101 & 243 & 465 & 354 \\
\hline & & D8 & $43^{\circ} 6.583 \mathrm{~N}$ & $5^{\circ} 27.227 \mathrm{E}$ & 307 & 187 & 237 & 212 \\
\hline & & D9 & $43^{\circ} 4.102 \mathrm{~N}$ & $5^{\circ} 25.519 \mathrm{E}$ & 1289 & 246 & 454 & 350 \\
\hline & \multirow{4}{*}{$\begin{array}{c}\text { Marum } \\
2009 \\
\text { Remora submersible }\end{array}$} & $\mathrm{R} 1$ & $43^{\circ} 6.977 \mathrm{~N}$ & $5^{\circ} 28.120 \mathrm{E}$ & 3851 & 320 & 530 & 425 \\
\hline & & R2 & $43^{\circ} 3.103 \mathrm{~N}$ & $5^{\circ} 24.978 \mathrm{E}$ & 5557 & 250 & 500 & 375 \\
\hline & & R3 & $43^{\circ} 7.060 \mathrm{~N}$ & $5^{\circ} 30.321 \mathrm{E}$ & 3774 & 230 & 530 & 380 \\
\hline & & R4 & $43^{\circ} 6.834 \mathrm{~N}$ & $5^{\circ} 27.925 \mathrm{E}$ & 2323 & 280 & 400 & 340 \\
\hline & $\begin{array}{c}\text { Ifremer } \\
\text { Cyatox } 1995 \\
\text { Cyana Submersible } \\
\end{array}$ & $1214-03$ & $43^{\circ} 7.000 \mathrm{~N}$ & $5^{\circ} 27.000 \mathrm{E}$ & 6276 & 292 & 646 & 469 \\
\hline & \multirow{3}{*}{$\begin{array}{c}\text { Ifremer } \\
\text { ESSROV } \\
2010 \\
\text { Victor } 6000 \text { ROV }\end{array}$} & 397-01 & $43^{\circ} 7.009 \mathrm{~N}$ & $5^{\circ} 28.162 \mathrm{E}$ & 998 & 251 & 400 & 326 \\
\hline & & 401-05 & $43^{\circ} 6.473 \mathrm{~N}$ & $5^{\circ} 27.284 \mathrm{E}$ & 4248 & 60 & 284 & 172 \\
\hline & & $407-11$ & $43^{\circ} 7.206 \mathrm{~N}$ & $5^{\circ} 28.846 \mathrm{E}$ & 3216 & 601 & 750 & 676 \\
\hline
\end{tabular}




\section{Table 3}

1424 List of fishes observed during MEDSEACAN 2009 cruise classified in three categories: Marketable (M), Edible (E) and Others $(\mathrm{O})$. The total abundance and maximum depth at which they were observed is mentioned. ( $\mathrm{M}^{*}$ ) Trachurus sp. is a pelagic marketable species that has been removed from the following of the study.

\begin{tabular}{|c|c|c|c|c|c|c|c|c|c|}
\hline $\begin{array}{l}\text { Class } \\
\text { Order }\end{array}$ & Family & Genus species & $\begin{array}{c}\text { Total effectif } \\
\text { observed }\end{array}$ & $\begin{array}{l}\text { Maximum } \\
\text { Depth } \\
\text { (m) }\end{array}$ & M & $E$ & 0 & English name & French name \\
\hline \multicolumn{10}{|l|}{ Actinopterygii } \\
\hline \multirow[t]{2}{*}{ Anguilliformes } & & sp.gen. & 1 & 442 & & & 0 & & \\
\hline & Congridae & Conger conger & 23 & 555 & & $E$ & & Conger & Congre \\
\hline \multirow[t]{2}{*}{ Aulopiformes } & Chlorophthalmidae & Chlorophthalmus agassizi & 8 & 464 & & & 0 & & \\
\hline & Synodontidae & Synodus saurus & 1 & 330 & & & 0 & & \\
\hline Beryciformes & Trachichthyidae & Hoplostethus mediterraneus & 29 & 599 & & & 0 & & \\
\hline \multirow[t]{14}{*}{ Gadiformes } & Gadidae & Gadiculus argenteus & 127 & 504 & & & 0 & & \\
\hline & & Lepidion lepidion & 1 & 686 & & $E$ & & Mediteranean codling & Morue Mediterranéenne \\
\hline & & Micromesistius poutassou & 16 & 655 & M & & & Poutassou / blue whiting & Merlan bleu \\
\hline & Lotidae & Molva macrophthalma & 6 & 448 & & $E$ & & Spanish ling & Lingue espagnole \\
\hline & Macrouridae & sp.gen. & 28 & 709 & & & 0 & & \\
\hline & & Coelorinchus caelorhincus & 192 & 579 & & & 0 & & \\
\hline & & Hymenocephalus italicus & 15 & 617 & & & 0 & & \\
\hline & & Nezumia aequalis & 16 & 708 & & & 0 & & \\
\hline & & Trachyrincus scabrus & 23 & 696 & & & 0 & & \\
\hline & Merluciidae & Merluccius merluccius & 57 & 645 & $M$ & & & Hake & Merlu / Colin \\
\hline & Moridae & sp.gen. & 5 & 618 & & & 0 & & \\
\hline & Phycidae & Phycis blennoides & 140 & 689 & & $E$ & & Greater forkbeard & Mostelle blanche de vase \\
\hline & & Phycis phycis & 2 & 360 & & $E$ & & Forkbeard & Mostelle brune de roche \\
\hline & & Phycis sp. & 4 & 320 & & $E$ & & Forkbeard & Mostelles \\
\hline Lophiiformes & Lophiidae & Lophius piscatorius & 8 & 456 & M & & & Monkfish & Lotte / Baudroie \\
\hline Myctophiformes & Myctophidae & sp. gen. & 21 & 670 & & & 0 & & \\
\hline Notacanthiformes & Notacanthidae & Notacanthus bonaparte & 7 & 619 & & & 0 & & \\
\hline \multirow[t]{3}{*}{ Ophidiiformes } & & sp. gen. & 4 & 473 & & & 0 & & \\
\hline & Carapidae & Echiodon dentatus & 1 & 431 & & & 0 & & \\
\hline & Ophidiidae & Benthocometes robustus & 5 & 634 & & & 0 & & \\
\hline Osmeriformes & Argentinidae & Argentina sphyraena & 57 & 408 & & & 0 & & \\
\hline \multirow[t]{13}{*}{ Perciformes } & Callionymidae & Synchiropus phaeton & 2 & 347 & & & 0 & & \\
\hline & Caproidae & Capros aper & 126 & 431 & & & 0 & & \\
\hline & Carangidae & Trachurus sp. & shoals & 488 & $M^{*}$ & & & Horse mackerel & Chinchard \\
\hline & Epigonidae & Epigonus denticulatus & 5 & 491 & & & 0 & & \\
\hline & & Epigonus telescopus & 2 & 423 & & & 0 & & \\
\hline & Labridae & Acantholabrus palloni & 35 & 381 & & & 0 & & \\
\hline & Mullidae & Mullus barbatus & 1 & 208 & & $E$ & & Red mullet & Rouget barbet (de vase) \\
\hline & & Mullus sp. & 3 & 320 & & $E$ & & & \\
\hline & Polyprionidae & Polyprion americanus & 3 & 627 & M & & & Wreckfish & Cernier \\
\hline & Serranidae & Anthias anthias & shoals & 239 & & & 0 & & \\
\hline & Sparidae & sp. gen. & 1 & 250 & & & 0 & & \\
\hline & & Pagellus sp. & 13 & 403 & $M$ & & & Sea-bream & Pageot \\
\hline & Trichiuridae & sp. gen. & 45 & 545 & $M$ & & & Cutlassfishes & Sabres \\
\hline \multirow[t]{2}{*}{ Pleuronectiformes } & Scophthalmidae & Lepidorhombus boscii & 56 & 580 & & $E$ & & Four spotted megrim & Cardine à 4 tâches \\
\hline & & Lepidorhombus whiffiagonis & 5 & 302 & & $E$ & & Megrim & Cardine franche \\
\hline \multirow[t]{4}{*}{ Scorpaeniformes } & Peristediifae & Peristedion cataphractum & 4 & 342 & & & 0 & & \\
\hline & Scorpaenidae & Scorpaena scrofa & 50 & 465 & M & & & Red scorpionfish & Rascasse rouge \\
\hline & Sebastidae & Helicolenus dactylopterus & 482 & 614 & & $E$ & & Blackbelly rosefish & Sebaste chèvre \\
\hline & Triglidae & sp. gen. & 22 & 476 & $M$ & & & Gurnards & Grondins \\
\hline
\end{tabular}




\begin{tabular}{|c|c|c|c|c|c|c|c|}
\hline & & Trigla lyra & 77 & 488 & M & Piper gurnard & Grondin lyre \\
\hline \multirow[t]{3}{*}{ Stomiiformes } & Stomiidae & sp. gen. & 1 & 705 & & b & \\
\hline & & Chauliodus sloani & 3 & 593 & & 0 & \\
\hline & & Stomias boa & 2 & 578 & & b & \\
\hline Syngnathiformes & Centriscidae & Macroramphosus scolopax & 3 & 262 & & b & \\
\hline Zeiformes & Zeidae & Zeus faber & 1 & 243 & M & & \\
\hline \multicolumn{2}{|l|}{ Elasmobranchii } & sp. gen. & 11 & 690 & & b & \\
\hline \multirow[t]{3}{*}{ Carcharhiniformes } & Scyliorhinidae & Scyliorhinus canicula & 35 & 394 & M & Lesser spotted dogfish & Petite roussette / saumonette \\
\hline & & Scyliorhinus sp. & 3 & 379 & M & & Roussettes \\
\hline & Triakidae & Galeus melastomus & 91 & 505 & $E$ & Black-mouthed dogfish & Chien espagnol \\
\hline Hexanchiformes & Hexanchidae & Hexanchus griseus & 1 & 366 & & b & \\
\hline Rajiformes & Rajidae & Raja sp. & 1 & 478 & & b & \\
\hline \multirow[t]{3}{*}{ Squaliformes } & Dalatiidae & sp.gen. & 4 & 481 & & b & \\
\hline & & Etmopterus spinax & 27 & 587 & & 0 & \\
\hline & & Oxynotus centrina & 1 & 225 & & b & \\
\hline
\end{tabular}
1428 